\title{
Soil carbon management in large-scale Earth system modelling: implications for crop yields and nitrogen leaching
}

\author{
S. Olin ${ }^{1}$, M. Lindeskog ${ }^{1}$, T. A. M. Pugh ${ }^{2}$, G. Schurgers ${ }^{3}$, D. Wårlind ${ }^{4}$, M. Mishurov ${ }^{1}$, S. Zaehle ${ }^{5}$, \\ B. D. Stocker ${ }^{6}$, B. Smith ${ }^{1}$, and A. Arneth ${ }^{2}$ \\ ${ }^{1}$ Department of Physical Geography and Ecosystem Science, Lund University, 22362 Lund, Sweden \\ ${ }^{2}$ Karlsruhe Institute of Technology, Institute of Meteorology and Climate Research/Atmospheric \\ Environmental Research, 82467 Garmisch-Partenkirchen, Germany \\ ${ }^{3}$ Department of Geosciences and Natural Resource Management, University of Copenhagen, \\ Øster Voldgade 10, 1350 Copenhagen, Denmark \\ ${ }^{4}$ CSIRO Sustainable Agricultural Flagship, CSIRO Agriculture, GPO Box 1666, Black Mountain, \\ Canberra, ACT 2601, Australia \\ ${ }^{5}$ Max Planck Institute for Biogeochemistry - Biogeochemical Integration Department, P.O. Box 600164 , \\ 07701 Jena, Germany \\ ${ }^{6}$ Department of Life Sciences, Imperial College London, Silwood Park, Ascot, SL5 7PY, UK
}

Correspondence to: S. Olin (stefan.olin@nateko.lu.se)

Received: 5 May 2015 - Published in Earth Syst. Dynam. Discuss.: 15 June 2015

Revised: 17 October 2015 - Accepted: 26 October 2015 - Published: 30 November 2015

\begin{abstract}
Croplands are vital ecosystems for human well-being and provide important ecosystem services such as crop yields, retention of nitrogen and carbon storage. On large (regional to global)-scale levels, assessment of how these different services will vary in space and time, especially in response to cropland management, are scarce. We explore cropland management alternatives and the effect these can have on future $\mathrm{C}$ and $\mathrm{N}$ pools and fluxes using the land-use-enabled dynamic vegetation model LPJ-GUESS (Lund-Potsdam-Jena General Ecosystem Simulator). Simulated crop production, cropland carbon storage, carbon sequestration and nitrogen leaching from croplands are evaluated and discussed. Compared to the version of LPJ-GUESS that does not include land-use dynamics, estimates of soil carbon stocks and nitrogen leaching from terrestrial to aquatic ecosystems were improved.

Our model experiments allow us to investigate trade-offs between these ecosystem services that can be provided from agricultural fields. These trade-offs are evaluated for current land use and climate and further explored for future conditions within the two future climate change scenarios, RCP (Representative Concentration Pathway) 2.6 and 8.5. Our results show that the potential for carbon sequestration due to typical cropland management practices such as no-till management and cover crops proposed in previous studies is not realised, globally or over larger climatic regions. Our results highlight important considerations to be made when modelling $\mathrm{C}-\mathrm{N}$ interactions in agricultural ecosystems under future environmental change and the effects these have on terrestrial biogeochemical cycles.
\end{abstract}




\section{Introduction}

Growing population along with rapidly changing dietary preferences pose one of the key economical and environmental challenges of this century (Gerland et al., 2014; Hertel, 2015). According to estimates made by the United Nations Food and Agriculture Organization (FAO), food production will need to be doubled by 2050 in order to meet the global food demand (FAO, 2008). Since the beginning of the 20th century there has been an increase in crop yields and overall production, especially since the 1950s (Steffen et al., 2015), as a result of agricultural intensification driven by substantial advances in agricultural practices and technology, improved crop varieties and an increased application of N and P fertiliser (Evans, 1999; Spano et al., 2003). In addition, agricultural land area has expanded globally, with around $35 \%$ of the total land surface presently being covered by cropland and pastures (Ramankutty et al., 2008).

Yield increases on existing land may be achieved through further development of high-yielding varieties or through further improvements in the efficiency of agricultural practices, the latter especially in regions where gaps between actual and potential yields are large (Licker et al., 2010; Mueller et al., 2014). The enhanced input of nitrogen (N) into ecosystems, jointly with other technical developments, has played a major role in the large increase in agricultural productivity over the last 50 years, often termed the "green revolution".

Due to their large areal extent, agricultural ecosystems have substantially altered global biogeochemical cycles (Rockstrom et al., 2009; Vitousek et al., 1997). So far, most studies focused on the greatest direct impacts of these changes, e.g. carbon losses following deforestation (Ciais et al., 2013; Houghton et al., 2012; Le Quéré et al., 2015). It is estimated that over the last 150-200 years, the conversion of natural to managed ecosystems, especially croplands, has released ca. $180 \mathrm{Pg}$ carbon (C; current rate is $\sim 1 \mathrm{Pg} \mathrm{C} \mathrm{yr}^{-1}$ ) from the terrestrial biosphere to the atmosphere by disturbing soils and through the harvesting and burning of biomass (Le Quéré et al., 2014). This sum is equivalent to around a third of the anthropogenic $\mathrm{CO}_{2}$ concentration in the atmosphere today. However, the land-use-related carbon flux is one of the most uncertain terms in the global carbon budget (Ciais et al., 2013; Le Quéré et al., 2015), and studies with dynamic vegetation models (DVMs) incorporating representations of land-use change (LUC) have shown that the actual estimate is highly dependent on the management practices assumed in the model (Bondeau et al., 2007; Levis et al., 2014; Lindeskog et al., 2013).

However, beyond the importance of land use and landuse change for understanding the global past and future carbon balance, other aspects of crop management also need to be investigated on large scales since the associated environmental effects have often been detrimental. Negative impacts have been noted for biodiversity and water quality and for the substantial emissions of $\mathrm{N}$ trace gases that affect air quality and climate, such as nitrous oxide $\left(\mathrm{N}_{2} \mathrm{O}\right)$, a potent greenhouse gas (Galloway et al., 2004; Rockstrom et al., 2009; Tilman et al., 2002; Vitousek et al., 1997). A large fraction of the $\mathrm{N}_{2} \mathrm{O}$ emitted to the atmosphere today originates from terrestrial sources, mostly from fertiliser use on agricultural soils (Zaehle et al., 2011; Park et al., 2012; Ciais et al., 2013). Fertiliser use also promotes nitrate leaching, which causes eutrophication and algal blooms in watersheds and coastal seas, with follow-on effects such as loss of fish populations and recreational value and health risks through contamination of drinking water (Cameron et al., 2013). Even in Europe, where environmental regulations are relatively advanced, a large portion of the population live in areas with high levels of nitrate in the drinking water (Grizetti, 2011).

Today's knowledge about the effects of interactions between global nitrogen and carbon cycles in terrestrial ecosystems is largely based on simulations with DVMs representing potential natural vegetation (e.g. Thornton et al., 2009; Zaehle and Dalmonech, 2011; Smith et al., 2014). The results obtained with these models suggest that soil $\mathrm{N}$ processes governing plant-available nitrogen can constrain vegetation growth and the strength of the terrestrial carbon sink (e.g. Zaehle et al., 2011; Wårlind et al., 2014). Only two global modelling frameworks have been put forward with both detailed cropland ecosystem functioning and coupled C-N cycling simulated in a consistent fashion (Arora, 2003; Drewniak et al., 2013). No study has applied such a model on a global scale to investigate joint impacts of environmental change and land management on associated changes in agricultural yields, water pollution and carbon balance, even though the production of food and the protection of the environment often require conflicting strategies and decision making, for instance between enhanced carbon sequestration rates (typically higher in forests than in croplands), food production (and enhanced nitrogen leaching), and other uses of land resources (Phalan et al., 2011). These trade-offs between agricultural production, on the one hand, and carbon sequestration and reduction in nitrogen leaching, on the other, have given rise to a number of mitigation strategies in agricultural practice that only have a limited impact on production but contribute to other ecosystem services.

Even though applied on the local to regional scale, landmanagement practices often have a large regional to global impact: via water pollution, greenhouse gas emissions or indirect land-use change (Tilman et al., 2002). One important practise discussed in relation to harvest is residue removal after harvest (Lal and Bruce, 1999). Removing residues for use in biofuel production is an appealing measure, as making multiple use of the existing croplands may be seen as a winwin situation (Lal, 2004b; Smith et al., 2012). However, not incorporating residues into soils results in the soils becoming drained of soil organic carbon (SOC); as SOC retains water and nutrients, reducing SOC reduces the soil fertility (Lal, 2004b; Smith et al., 2012). Another practice that is often debated is tillage (Lal, 2004a, 2008). Different forms of 
tillage have been used for centuries to promote the release of nutrients from the soil organic matter (SOM) for uptake by crops. However, the aeration of the soil associated with the mechanical disturbance of the soil profile increases heterotrophic respiration $\left(R_{\mathrm{h}}\right)$ and thus enhances soil C losses to the atmosphere (Chatskikh et al., 2009; Lal, 2004b). Notill management has gained popularity as a potential climate change mitigation measure, as it can prevent managementrelated losses of soil C stocks (Lal, 2004b). However, while no-till management is expected to favour carbon retention by agricultural fields, the strength and persistence of any sink is debated (Lal, 2004a; Schlesinger, 2000). In a review of soil $\mathrm{C}$ sequestration, comparing conventional and no-till management, Baker et al. (2007) found that the top soil in no-till treatments did contain more $\mathrm{C}$, but the $\mathrm{C}$ density below the top soil layer in the conventionally tilled fields was higher and there was no significant difference in overall $\mathrm{C}$ densities between the two treatments. Moreover, the conversion of $\mathrm{N}$ to plant-available forms is reduced in untilled soils and can thus lead to lower crop productivity. Although no-till farming is applied partially to improve water and nutrient retention, the reduced crop productivity and thus reduced input of new organic material could also decrease the soil's organic content in the long run (Lal, 2004b).

Appropriate nutrient management can increase SOC sequestration (Lal, 2004b), especially under elevated $\left[\mathrm{CO}_{2}\right]$ (Van Kessel et al., 2000). However, the N-fertiliser effect on SOC can be offset by the carbon cost of energy intensive manufacturing of fertilisers (Lal, 2004a). Application of manure generally increases the SOC and has a positive effect on soil fertility (Lal, 2004b). Instead of mitigating climate change, the negative effects of the use of $\mathrm{N}$ fertilisers on agricultural fields ( $\mathrm{N}$ leaching and volatilisation) can also, if not managed appropriately, contribute to it through emissions of, e.g., $\mathrm{N}_{2} \mathrm{O}$, which is a potent greenhouse gas (Zaehle et al., 2011).

In this study we employ the land-use-enabled version of a global DVM, LPJ-GUESS (Lund-Potsdam-Jena General Ecosystem Simulator) (Lindeskog et al., 2013; Olin et al., 2015), to explore and quantify the effectuality of alternative management strategies (such as no-till, cover crops and manure) that aim to mitigate the negative effects of agriculture on carbon and nitrogen cycles. To this end, we extended the model to include $\mathrm{N}$ dynamics for crops, and the response of different $\mathrm{N}$-application rates was evaluated on the local to regional scale. Management options considered are tillage, cover crops and manure application. We cannot yet assess the effects of management on soil $\mathrm{N}_{2} \mathrm{O}$ emissions, as work to do so is still in progress. We quantify management effects on soil carbon pools, yields and nitrogen losses through leaching from croplands and evaluate the model globally and for a representative range of climatic regions. In addition, the persistence and direction of these effects under future climate change scenarios are explored.

\section{Materials and methods}

\subsection{LPJ-GUESS}

LPJ-GUESS (Smith et al., 2014) is a DVM that simulates dynamic vegetation response to climate, atmospheric $\mathrm{CO}_{2}$ levels $\left(\left[\mathrm{CO}_{2}\right]\right)$ and $\mathrm{N}$ input through competition for light, $\mathrm{N}$, and water on a daily time step. Vegetation is represented by plant functional types (PFTs) that differ in their growth form, phenology, life-history strategy, distributional temperature limits and $\mathrm{N}$ requirements. $\mathrm{C}_{3}$ and $\mathrm{C}_{4}$ photosynthetic pathways are discriminated for grasses. Leaf-level net photosynthesis is calculated following a Farquhar-type approach, modified by Collatz et al. $(1991,1992)$ and scaled to the canopy following Haxeltine and Prentice (1996). Plant N demand is determined through optimal leaf $\mathrm{N}$ content for photosynthesis, based on the optimisation of the carboxylation capacity of rubisco (Haxeltine and Prentice, 1996). Canopy conductance of water vapour and respiration of plant compartments other than leaves are modelled following Sitch et al. (2003). For potential natural vegetation, carbon allocation and stand dynamics are modelled on a yearly time step. Stand dynamics are based on competition among age classes of trees cooccurring in a number (here 5) of replicated patches in each grid cell (Smith et al., 2001; Hickler et al., 2004). Disturbance by wildfire and other events such as storms are accounted for. Details of the representation of soil and plant physiological and growth processes are provided in Smith et al. (2001, 2014) and Olin et al. (2015).

Soil C-N dynamics in LPJ-GUESS are based on the Century model (Parton et al., 1993), in which SOM and litter are represented by 11 pools that differ in their $\mathrm{C}$-to- $\mathrm{N}$ ratios $(\mathrm{C}: \mathrm{N})$, which are dynamic within prescribed limits (Smith et al., 2014). Mobilisation of mineral $\mathrm{N}$ is the result of heterotrophic decay and respiration which depends on the $\mathrm{C}: \mathrm{N}$ and decay rates $\left(K_{\mathrm{d}}\right)$ of the SOM pools. Values of $K_{\mathrm{d}}$ are dynamic and vary between these pools, and they are also modified by temperature and water content of the soil (Smith et al., 2014). Organic $\mathrm{N}$ is mineralised when transferred SOM, after a fraction of transferred $\mathrm{C}$ is respired (heterotrophic respiration), has a higher $\mathrm{N}$ content than the receiving pool $\mathrm{N}$ demand. Immobilisation occurs when receiving pools' $\mathrm{N}$ demand exceeds transferred $\mathrm{N}$ content and the deficit has to be meet by available soil mineral N. Mineral N available after mineralisation and immobilisation is further depleted by plant $\mathrm{N}$ uptake, which is directly proportional to plant fine root $\mathrm{C}$ mass with constraints imposed by the soil mineral $\mathrm{N}$ pool itself, plant $\mathrm{N}$ status, and soil temperature (Zaehle and Friend, 2010). Mineral N leaching is then possible on the remaining mineral $\mathrm{N}$ and is related to percolation. Leaching of organic $\mathrm{N}$ is also represented in the model and relates to the decomposition of active SOM, percolation and soil silt and clay fractions.

The present study uses the managed land version of the model (Lindeskog et al., 2013; Olin et al., 2015). Land-use 
and land cover change are modelled on a yearly basis based on the externally supplied fractional area change within a grid cell. Pastures are modelled to represent a mean grazed or harvested grassland with a harvest of $50 \%$ of the aboveground biomass annually; the rest, together with the root biomass is returned to the soil as litter (Lindeskog et al., 2013). Crops are represented in the model by crop functional types (CFTs), which differ in their temperature requirements for survival, heat requirements for growth and their $\mathrm{C}$ allocation patterns. Sowing dates are determined dynamically in the model based on the prevailing climate in the grid cell (Lindeskog et al., 2013; Waha et al., 2011), and crops are harvested when specified heat sum requirements (accumulation of degree days above a crop-specific base temperature) are fulfilled (Lindeskog et al., 2013). The crops are allowed to adapt to the local conditions by adjusting the heat sum requirements to the historic climate (Lindeskog et al., 2013), reflecting a difference in varieties of a given crop grown in different climatic zones.

The allocation of $\mathrm{C}$ and $\mathrm{N}$ for the CFTs in the $\mathrm{C}-\mathrm{N}$ version of LPJ-GUESS (Olin et al., 2015) is done on a daily time step. $\mathrm{C}$ allocation depends on the plant's development stage (DS), which in turn is based on temperature and day length, and follows Penning de Vries et al. (1989), as described in detail for winter and spring wheat in Olin et al. (2015) and for maize in Table A1. DS is a number between 0 and 2 and describes the developmental phases in a crop plant; a DS below 1 represents the period during which the crop plant allocates most of the assimilates to growth and values between 1 and 2 correspond to the grain-filling phase. $\mathrm{N}$ requirements for the plant vary during the growing period. This is reflected in the model by applying fertilisers proportionally at different developmental stages; see the Appendix for more information on the timing of $\mathrm{N}$-fertiliser application for different CFTs. At harvest, the grains together with a portion of the residues are removed from the field. In the model, harvest is not perfect; $10 \%$ of the grain and residue $\mathrm{C}$ and $\mathrm{N}$ is left as litter and decomposes (see the section "Residue removal" below).

At present, the C-N version of LPJ-GUESS is limited to three CFTs, which are based on wheat and maize growth characteristics: a C3 crop with dynamic selection between spring and autumn sowing (represented here by winter wheat, WW), a C3 crop with sowing carried out in spring (spring wheat, SW) and a C4 crop (maize, MA). Allocation for SW and WW is described in Olin et al. (2015); MA-specific allocation parameters are listed in Tables A1-A2. For comparison with yield data, we adopt these three types to represent the entire spectrum of crops grown globally. In particular, wheat and rapeseed that have spring- and autumn-sown varieties were simulated as WW, whereas other $\mathrm{C} 3$ crops (beans, rice, tubers, etc.) were modelled as SW, since these are typically spring sown. Sorghum and millet were modelled as MA.
LPJ-GUESS has been evaluated against a range of experimental and observational data types, e.g. $\mathrm{CO}_{2}$-fertilisation experiments (Olin et al., 2015; Smith et al., 2014), ecosystem dynamics (Smith et al., 2014), vegetation seasonality (Lindeskog et al., 2013) and C fluxes on various scales (Ahlström et al., 2012; Piao et al., 2013; Wramneby et al., 2008). In Olin et al. (2015), the growth response to $\mathrm{N}$-fertiliser application on site scale (under ambient and elevated $\mathrm{CO}_{2}$ ) and over a larger region (western Europe) was evaluated.

\subsubsection{Cropland management}

The cropland management options implemented in LPJGUESS are sowing, irrigation, tillage, $\mathrm{N}$ application, cover crops and residue management. The latter four options are relevant for this study and will be described below.

\section{Tillage}

Tillage is implemented using a tillage factor $\left(f_{\mathrm{T}}\right)$, which affects $K_{\mathrm{d}}$ for selected SOM pools on croplands. Two tillage routines were implemented: moderate tillage where $f_{\mathrm{T}}$ affects the $K_{\mathrm{d}}$ of the surface humis and microbial pools, as well as the microbial and slow turnover pools of the soil, and full tillage in which $K_{\mathrm{d}}$ for the metabolic and structural surface pools and the passive and metabolic pools of the soil are also affected. The two tillage levels are not intended to represent different tillage practices but rather to span uncertainties in the overall effect of tillage on soil respiration rates. The value of $f_{\mathrm{T}}$ (1.94) is taken from Chatskikh et al. (2009) and modifies $K_{\mathrm{d}}\left(K_{\mathrm{d}}^{\prime}=f_{\mathrm{T}} K_{\mathrm{d}}\right)$ throughout the year.

\section{$\mathrm{N}$ application}

Fertilisers are applied as mineral N (Olin et al., 2015). The timing of fertiliser applications in the model roughly coincides with the crucial developmental periods of plants: applications take place at DSs $0,0.5$ and 0.9 (Olin et al., 2015) in the CFT-specific amounts listed in Table A2.

Here we have extended the available $\mathrm{N}$-fertiliser application management options to also include manure application in the first of the three events (DS $=0$; sowing).

The amount of manure is derived using the mineral $\mathrm{N}$ application rate but applying the increase in the metabolic and structural SOM pools rather than in the mineral $\mathrm{N}$ pool, with a $C: N$ of 30 . This means that 30 units of $C$ are also added for every unit of $\mathrm{N}$. The $\mathrm{C}: \mathrm{N}$ has been chosen to represent the $\mathrm{C}$ and $\mathrm{N}$ content in manure from sources ranging from poultry waste $(\mathrm{C}: \mathrm{N} \sim 15)$ to straw-rich manure from livestock $(C: N \gtrsim 40)$ (Nieder and Benbi, 2008). As the metabolic and structural SOM pools have different turnover (decomposition) rates, the manure-derived $\mathrm{N}$ becomes available for an extended period in the soil. 
Table 1. Summary of simulation experiments; for abbreviations and further explanations, see text.

\begin{tabular}{|c|c|c|c|c|c|c|}
\hline Purpose of experiment & Time period & $\begin{array}{c}\text { Spin-up period } \\
\text { and }\left[\mathrm{CO}_{2}\right]\end{array}$ & $\begin{array}{l}\text { Land-use change } \\
\text { during spin-up }\end{array}$ & $\begin{array}{c}\text { Climate } \\
\text { data }\end{array}$ & $\mathrm{N}$-fertiliser data & $\begin{array}{c}\text { Land-use } \\
\text { change data }\end{array}$ \\
\hline $\begin{array}{l}\text { Response to different } \\
\text { management regimes; } \\
\mathrm{C} \text { and } \mathrm{N} \text { pools and fluxes; } \\
\text { historical }\end{array}$ & 1901-2006 & $\begin{array}{c}500 \text { years, } \\
1901\left[\mathrm{CO}_{2}\right]\end{array}$ & $\begin{array}{c}\text { Started } 350 \text { years } \\
\text { into spin-up, linear } \\
\text { increase to } 1901\end{array}$ & $\mathrm{CRU}$ & Zaehle et al. (2010a) & Hurtt et al. (2011) \\
\hline $\begin{array}{l}\text { Yield comparison; } \\
\text { historical }\end{array}$ & 1901-2006 & $\begin{array}{l}500 \text { years, } \\
1901\left[\mathrm{CO}_{2}\right]\end{array}$ & $\begin{array}{l}\text { Started } 350 \text { years } \\
\text { into spin-up, linear } \\
\text { increase to } 1901\end{array}$ & CRU & $\begin{array}{l}\text { Zaehle et al. (2010a) } \\
\text { until 1990; thereafter } \\
\text { Elliott et al. (2014) }\end{array}$ & Hurtt et al. (2011) \\
\hline $\begin{array}{l}\text { Response to different } \\
\text { management regimes; } \\
\text { future }\end{array}$ & $1850-2100$ & $\begin{array}{l}450 \text { years, } \\
1901\left[\mathrm{CO}_{2}\right]\end{array}$ & $\begin{array}{l}\text { Started } 300 \text { years } \\
\text { into spin-up, linear } \\
\text { increase to } 1850\end{array}$ & CMIP5 & Zaehle et al. (2010a) & Hurtt et al. (2011) \\
\hline $\begin{array}{l}\text { C sequestration response; } \\
\text { soil C comparison; historical }\end{array}$ & $1901-2100$ & $\begin{array}{l}500 \text { years, } \\
1901\left[\mathrm{CO}_{2}\right]\end{array}$ & $\begin{array}{l}\text { Started } 350 \text { years } \\
\text { into spin-up, linear } \\
\text { increase to } 1901\end{array}$ & $\begin{array}{l}\text { CRU, after 2006: } \\
1977-2006 \\
\text { repeated until } 2100\end{array}$ & Zaehle et al. (2010a) & $100 \%$ cropland \\
\hline
\end{tabular}

\section{Cover crops}

Cover crops are intermediate crops that are grown in-between the main agricultural growing seasons either as a fallow that stretches over the subsequent growing season or within the same year (Follett, 2001). A common practice is to sow $\mathrm{N}$ fixing plants such as legumes as cover crops, but grasses are also used. If the cover crop is not harvested but, for example, ploughed in, some of the captured or retained nutrients, as well as the carbon content of the crop biomass, are retained in the soil, enhancing nutrient availability.

In our implementation, cover crops are grown in-between two growing periods of the generic main crop used if the crop-free period is longer than 15 days. At the time of sowing of the subsequent main crop, the cover-crop biomass is added to the soil litter pool. $\mathrm{C}$ and $\mathrm{N}$ allocation of the cover crop is done daily, with a leaf-to-root ratio that depends on the plant water status. In case of water stress, a functional balance response is introduced and allocation to roots increases relative to leaves. Cover crops are modelled as grasses, being "planted" with an initial C mass of $0.01 \mathrm{~kg} \mathrm{C} \mathrm{m}^{-2}$ and with an $\mathrm{N}$ mass that is based on the $\mathrm{C}: \mathrm{N}_{\min }$ value for grasses $\left(C: N_{\min }=16\right)$. Symbiotic $\mathrm{N}$ fixation, such as in legumes, which are common as cover crops in temperate latitudes, is not yet implemented.

\section{Residue removal}

A measure to increase the soil fertility and decrease the water loss, in particular in arid areas, is to leave the residues on the ground after harvest (Lal, 2004a; Smith et al., 2012). This practice is represented in our model by removing only a fraction (default set to $75 \%$ ) of the biomass remaining following harvest, thus leaving the rest as litter, which enters the normal soil-decomposition calculations. While this affects soil $\mathrm{C}$ content, the effect of crop residues on soil evaporation and hence soil water content is not represented in the model.

\subsection{Experimental set-ups}

Our study is divided into two parts. In the first part we test the ability of LPJ-GUESS to simulate present-day soil C and the yield response to management by comparing simulated results with data sets of soil $\mathrm{C}$ in crop fields, potential $\mathrm{C}$ sequestration after a change in management, and global yield statistics. In the second part of the study, we investigate the efficacy of alternative crop management options described in Sect. 2.1.1 for mitigating climate change through increased carbon retention in cropland soils. The sensitivity of soil carbon sequestration to these management options is first studied for present-day climate conditions, assessing relative effects in different regions. Subsequently, we force the model with general circulation model (GCM)-simulated climate under a 21 st-century future climate projection to investigate combined effects of future changes in multiple ecosystem drivers on cropland ecosystem carbon balance. Below, the set-up of the different experiments are explained in detail; a summary is also available in Table 1.

For the simulation of the recent historic period (19012006), gridded monthly mean observations of precipitation, air temperature and cloudiness from CRU (Climate Research Institute; Mitchell and Jones, 2005) were used. For the future-climate simulations, monthly climate data were adopted from four CMIP5 (Coupled Model Intercomparison Project Phase 5) GCMs: CCSM4 (Community Climate System Model version 4) (Gent et al., 2011), MPI-ESMLR (Max Planck Institute Earth System Model, low resolution; e.g. Stevens et al., 2013), IPSL-CM5A-LR (Institut Pierre Simon Laplace coupled model version 5A, low resolution). For the simulation of the recent historic (Dufresne et al., 2013) and HadGEM2-ES (Hadley Centre Global Environmental Model, version 2, Earth system) (Collins et al., 2011). The GCM climate data cover period between 1850 and 2100 (Taylor et al., 2011) and were bias corrected against CRU for monthly means over the period from 1961 to 1990, as described in Ahlström et al. (2013). Climate data for the 
contrasting RCPs (Representative Concentration Pathways) 2.6 and 8.5 radiative forcing projections (Moss et al., 2010) were selected based on the availability of projections of future $\mathrm{N}$ fertilisation.

For all simulations soil $\mathrm{C}$ and $\mathrm{N}$ pools were initialised with a "spin-up" using atmospheric $\left[\mathrm{CO}_{2}\right]$ from the first historic year (1901 for the historical CRU-based simulations and 1850 for the CMIP5 simulations) combined with repeatedly cycled, detrended climate input using the first 30 years of the historic climate data set. The spin-up period for the CRU simulations was set to 500 years. In order to make the CMIP5 simulations comparable to the simulations using CRU, the spin-up was set to 450 years, followed by a simulation for the years 1850-1901 with dynamic climate but constant $\left[\mathrm{CO}_{2}\right]$ (using the $\left[\mathrm{CO}_{2}\right]$ for 1901).

$\mathrm{N}$ atmospheric deposition was provided as decadally varying monthly averages from the ACCMIP (Atmospheric Chemistry and Climate Model Intercomparison Project) data set (Lamarque et al., 2010) transformed to the resolution of the climate data following Smith et al. (2014) and Wårlind et al. (2014).

As N-fertiliser input for the croplands, data from Zaehle et al. (2010a) were used for the historical time period, starting from 1901 (CRU) and 1850 (CMIP5); for the future period (2006-2100), a data set described in Stocker et al. (2013) was used, which expands on the data set from $\mathrm{Za}-$ ehle et al. (2010a) and includes simulated future fertiliser applications from integrated assessment models (RCP2.6 Bouwman et al., 2013; RCP8.5 - Riahi et al., 2011). The total global $\mathrm{N}$ fertiliser applied is visualised in Fig. A1a. In addition, a simulation using $\mathrm{N}$-fertiliser information from $\mathrm{Ag}$ GRID (AgMIP GRIDded Crop Modeling Initiative) (Elliott et al., 2014) was performed for the comparison of yields with national statistics from the FAO. The Ag-GRID data set provides a long-term mean $\mathrm{N}$-fertiliser input for each grid cell representing the present day (approximately the year 2000). In these simulations the input from Zaehle et al. (2010a) was used until 1990, subsequently switching over to Ag-GRID data.

Land cover information was adopted from Hurtt et al. (2011), with data on historic and future cropland, pasture and natural vegetation. The additional land cover classes in the data set (forested, rangeland and urban classes) were treated as natural land cover. During spin-up, cropland fraction was linearly increased from an assumed baseline of zero in 1750 to the first historic value (1901 for CRU and 1850 for CMIP5). The number of years for this transition (150 years for the CRU-based and 100 years for the CMIP5 simulations) was chosen to ensure that the soil $\mathrm{C}$ and $\mathrm{N}$ pools of the natural vegetation fraction of each grid cell reached steady state by the beginning of the transition period. The different period lengths were chosen to make the simulations comparable in terms of land-use change prior to 1901 . While this procedure will likely result in higher SOM pools in areas such as central Europe, India and the Middle East, where agriculture has been present for many centuries, it will be most realistic for regions where most agricultural expansion has taken place over the last 100-200 years. Grid cell fractions of crop coverage for those grid cells where data on crop species exist were taken from MIRCA (Monthly Irrigated and Rainfed Crop Areas) (Portmann et al., 2010) and aggregated to the three CFTs as described in Sect. 2.1. The relative CFT cover fractions were conserved over time, and information from the neighbouring cells was used using a distance weighted mean for grid cells that lack information in the MIRCA data set.

As soil input, a soil map with fractions of clay, silt and sand from the WISE 3.0 (Wide-field Infrared Survey Explorer, version 3) data set (Batjes, 2005) were used. Hydrological properties of the soil were calculated following Eqs. (19)-(20) from Olin et al. (2015).

\subsubsection{Soil carbon and management response}

To evaluate LPJ-GUESS ability to simulate soil C density and sequestration, soil columns from croplands in the WISE 3.0 data set (Batjes, 2005) were compared to modelled cropland soil C. Soil carbon from the top $1.5 \mathrm{~m}$ of the soil columns was associated with a $0.5^{\circ}$ grid cell matching the climate data used in this study. If more than one sample was available within the approximately 1000 grid cells that had soil $\mathrm{C}$ information, the data were averaged to give a single number per grid cell. As no detailed information was available on the management or land-use history for the different soil column sites, the CFT fractions from Portmann et al. (2010) were used together with $\mathrm{N}$-fertiliser input as described above.

In Stockmann et al. (2013), data on long-term soil carbon response to the management options (cover crops, no-tillage and manure application) were divided between four climatic regions: humid temperate, dry temperate, humid tropical and dry tropical. In order to compare our simulated carbon sequestration with the findings of Stockmann et al. (2013), each simulated grid cell for which observed soil column data were available was classified to be either tropical $\left(24^{\circ} \mathrm{S}>\right.$ latitude $\left.<24^{\circ} \mathrm{N}\right)$ or temperate $\left(24^{\circ} \mathrm{S}<\right.$ latitude $>24^{\circ} \mathrm{N}$ and latitude $\left.<60^{\circ} \mathrm{N}\right)$, as depicted in Fig. A3. These categories were further subdivided into dry if the water balance coefficient $(\mathrm{WBC}=$ precipitation - potential evapotranspiration $)$ was negative and humid if it was positive. Each of the resulting four classes covered approximately 200 grid cells, evenly spread over the continents (Fig. A3). Some 200 of the grid cells were either in the boreal zone or not included in the climate data set. To be able to show the effect of the studied management practices during the historic period, these were enabled starting in the year 1990 until the end of the simulation period. For the simulations using CRU climate input, the last 30 years of climate and $\left[\mathrm{CO}_{2}\right]$ ( $\left.381 \mathrm{ppmv}\right), \mathrm{N}$ deposition and fertiliser from the last year were repeated until 2100, the end of the CMIP5 climate data set, in order to allow soil car- 
bon and nitrogen pools to reach a new equilibrium after the management shift.

\subsubsection{Management, global soil $\mathrm{C}$ and $\mathrm{N}$ leaching}

The effect of the different management strategies considered (no-tillage (NT), manure application (MN), cover crops (CC), leaving all residues (NR); Table 2.1.1) on simulated global crop yields, soil $\mathrm{C}$ pool size, and $\mathrm{N}$ leaching was tested in a factorial experiment where management types were turned on at the beginning of the simulation. The simulated yields, soil $\mathrm{C}$ and $\mathrm{N}$ leaching were then compared with a baseline simulation $\left(F_{\text {std }}\right.$, Table 2$)$ with settings as in Lindeskog et al. (2013) Smith et al. (2014) and Olin et al. (2015).

To be able to compare our results with previous estimates of global soil $\mathrm{C}$ and $\mathrm{N}$ pools and $\mathrm{N}$ leaching from LPJGUESS (Smith et al., 2014), a simulation with potential natural vegetation (PNV) was also conducted. In addition, an optimised simulation set-up was selected $\left(F_{\text {opt }}\right)$, in which the management from Table 2 that yielded the largest increase in soil carbon per grid cell was selected for the CRU and CMIP5 simulations.

\section{Results}

\subsection{Yield comparison}

LPJ-GUESS wheat (C3) and maize (C4) yields were simulated using the gridded $\mathrm{N}$-fertiliser data set (Elliott et al., 2014) and compared to reported yields from $\mathrm{FAO}^{1}$ for the years 1996-2005 (Fig. 1). The overall model agreement with reported wheat yields per country was good across all wheat-producing countries, with a correlation coefficient of 0.73 and root mean square error (RMSE) value of $1.5 \mathrm{tha}^{-1} \mathrm{yr}^{-1}$. Maize yields had a lower agreement (correlation coefficient 0.46 ; RMSE $4.3 \mathrm{tha}^{-1} \mathrm{yr}^{-1}$ ), with simulated yields overestimating the observations for most countries that have a low maize production (e.g. Mexico, China and many African countries; Fig. 1). However, with the exception of China and Mexico, yields in highly productive countries were captured well, including the largest producer, the USA, despite the model not being directly calibrated against these yields.

The total simulated production (wet weight) of all agricultural crops (including cereals, tubers and pulses) of $2.7 \mathrm{Gt}$ was within $30 \%$ of what is reported to the FAO: $3.5 \mathrm{Gt}$ for the period 1996-2005 (cereals, $2.12 \mathrm{Gt}$; coarse grain, $0.93 \mathrm{Gt}$; roots and tubers, $0.28 \mathrm{Gt}^{2}$; pulses, $0.06 \mathrm{Gt}$; oil crops, $0.11 \mathrm{Gt}$ ). In Fig. A2, a comparison between modelled crop production and that from FAOSTAT is shown.

\footnotetext{
${ }^{1}$ FAOSTAT, http://faostat3.fao.org/home/E

${ }^{2}$ Corrected for moisture content; value from FAOSTAT: $0.68 \mathrm{Gt}$.
}

Table 2. Simulation settings used for the comparison of soil $\mathrm{C}$, yields and $\mathrm{N}$ leaching with different agricultural management types. For implementation of full vs. moderate tillage, see Sect. 2.1.1. In the row headed "scenario", the management types that are included in the different scenario simulations are indicated. Abbreviations: NT - no-tillage; MN - manure application; CC - cover crops; and $\mathrm{NR}$ - leaving all residues.

\begin{tabular}{lcccccc}
\hline Simulation & $F_{\text {std }}$ & $F_{\mathrm{NT}}$ & $F_{\mathrm{MN}}$ & $F_{\mathrm{CC}}$ & $F_{\mathrm{MT}}$ & $F_{\mathrm{NR}}$ \\
\hline Tillage & full & no & full & full & modest & full \\
Manure N & no & no & yes & no & no & no \\
Cover crops & no & no & no & yes & no & no \\
Residue removal & 75 & 75 & 75 & 75 & 75 & 0 \\
Scenario & yes & yes & yes & yes & no & no \\
\hline
\end{tabular}

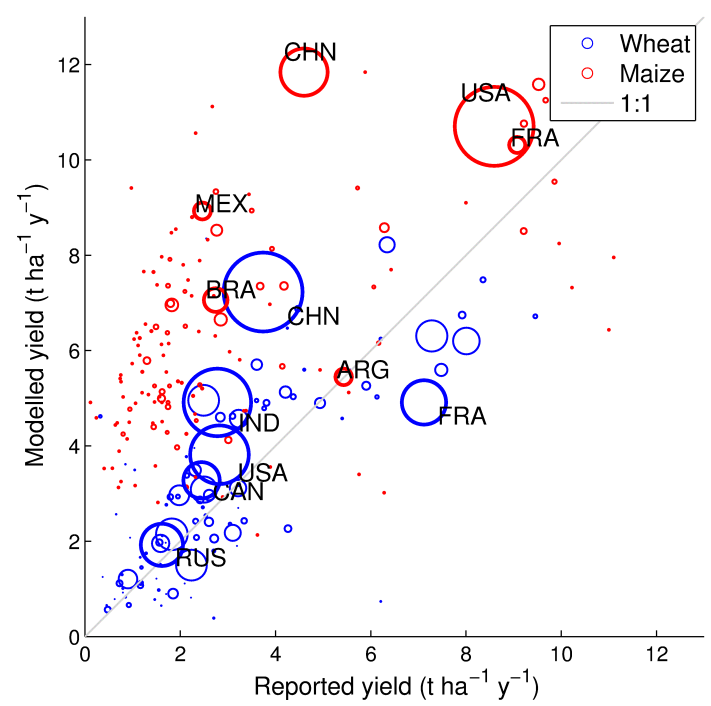

Figure 1. Per-country comparison of simulated yields for WW (wheat) and MA (maize) against reported yields from FAO (1996-2005). Marker size indicates each country's total production. The top six producer countries of both crops are labelled with the following abbreviations: ARG - Argentina; BRA - Brazil; CAN Canada; CHN - China; FRA - France; IND - India; MEX - Mexico; RUS - Russia; USA - United States.

\subsection{Simulated soil $\mathrm{C}$ and its response to management}

Simulated soil C pools $(0-1.5 \mathrm{~m})$ for the selected grid cells (Sect. 2.2.1) were compared against data from soil cores from agricultural fields for the four climatic regions (Batjes, 2005). This comparison did not aim to reproduce observed $\mathrm{C}$ values on the individual field scale, as this would require to capture individual site meteorology as well as details on land-use history. Consequently, per-site comparison of simulated vs. observed soil $\mathrm{C}$ resulted in low correlations of $0.05-0.14$, but the mean and spread over the climatic zones were captured by the model (Table 3 ).

In Fig. 2, the simulated mean soil $\mathrm{C}$ sequestration response to the three management types (no-till, manure and cover crops) is compared to estimates of potential soil C seques- 


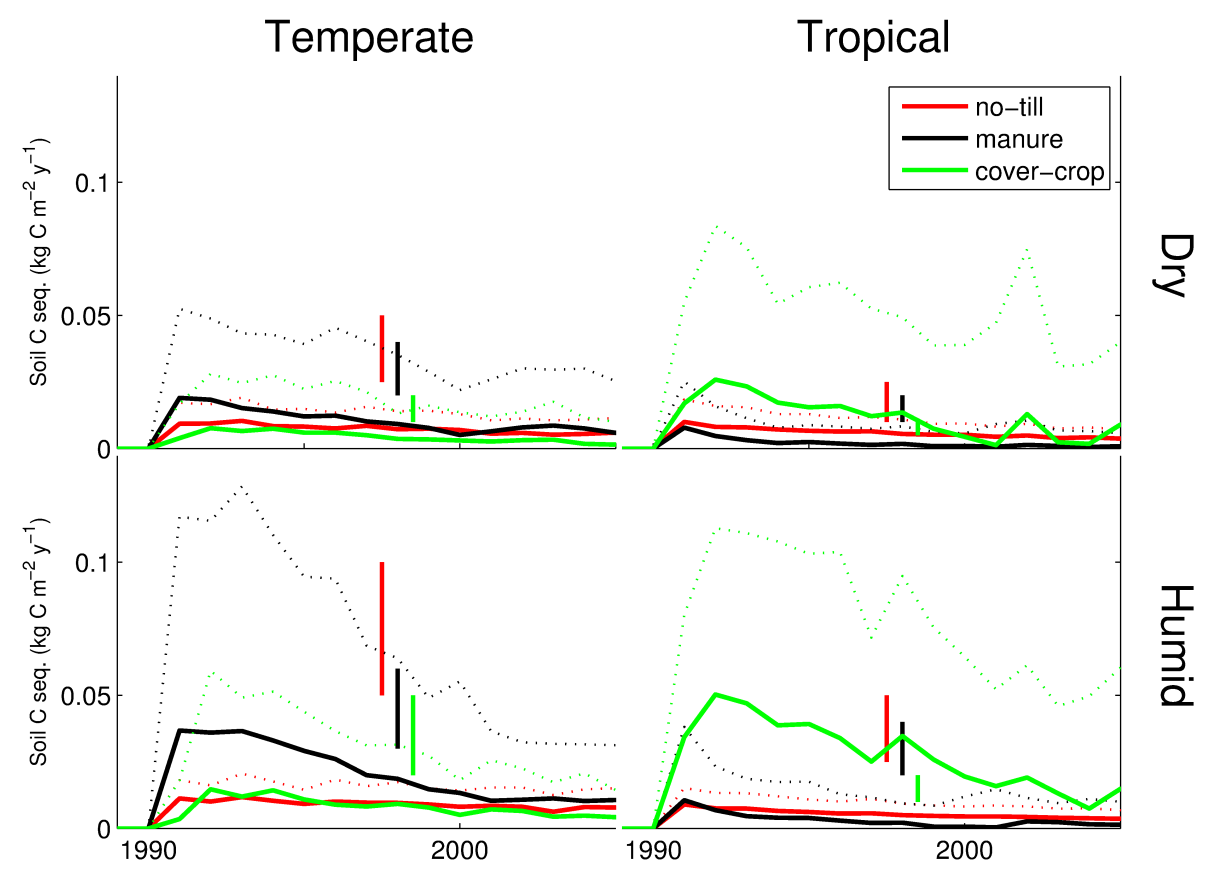

Figure 2. Simulated mean C sequestration following the implementation of management over the CRU historic period on agricultural soils averaged (thick lines) for the selected grid cells in the four climatic regions, compared to estimates (vertical lines) from Stockmann et al. (2013). Dotted lines indicate the mean plus 2 SD (standard deviations) from all grid cells in each climatic region. The vertical lines do not represent specific years but the potential over time to sequester $\mathrm{C}$ on cropland soils.

tration from Stockmann et al. (2013) for the simulated climatic regions over the historic period (1990-2006). Besides the model's average regional response to the three management options, Fig. 2 illustrates how the soil $\mathrm{C}$ sequestration in response to the onset of management (here in the year 1990; see Sect. 2.2.1) evolves over time. The simulated long-term (100-year) mean soil C sequestration by using manure on tropical soils was ca. $0.001 \mathrm{~kg} \mathrm{C} \mathrm{m}^{-2} \mathrm{yr}^{-1}$, declining to negligible levels by the end of the simulated period. For no-till management, the long-term mean $\mathrm{C}$ sequestration was $0.003 \mathrm{~kg} \mathrm{C} \mathrm{m}^{-2} \mathrm{yr}^{-1}$ or higher for all treatments, and levelled off to ca. $0.002 \mathrm{~kg} \mathrm{C} \mathrm{m}^{-2} \mathrm{yr}^{-1}$ in the simulated year 2100. The highest mean $\mathrm{C}$ sequestration rates were found for manure in the humid temperate climatic regions $\left(0.006 \mathrm{~kg} \mathrm{C} \mathrm{m}^{-2} \mathrm{yr}^{-1}\right)$ and for cover crops in the tropical humid regions $\left(0.008 \mathrm{~kg} \mathrm{C} \mathrm{m}^{-2} \mathrm{yr}^{-1}\right)$, in both cases levelling off to below $0.001 \mathrm{~kg} \mathrm{C} \mathrm{m}^{-2} \mathrm{yr}^{-1}$ by the end of the simulation period.

\subsection{Global responses to management}

The simulated management options resulted in an increase in cropland soil C, for all climatic regions (Fig. 3), with the largest global increase, as expected, for the option in which the management that yielded the largest carbon sequestration in a given grid cell was chosen $\left(F_{\text {opt }}\right)$. With the exception of no residue removal, the simulated management treatments reduced $\mathrm{N}$ leaching (expressed here as negative anomalies),
Table 3. Soil C pools $(0-1.5 \mathrm{~m})$ in four climatic regions, observed (Batjes, 2014) and simulated, with the 0.05 and 0.95 percentiles in parenthesis. In the last two columns, the correlation coefficients and the $p$ values are shown to demonstrate that there is a positive relationship between simulated and observed values.

\begin{tabular}{llllc}
\hline & \multicolumn{2}{c}{ Soil C $\left(\mathrm{kg} \mathrm{C} \mathrm{m}^{-2}\right)$} & & \\
\cline { 2 - 3 } Climatic region & Observed & Simulated & Corr. & $P$ \\
\hline Temperate, dry & $5.7(1.3-12.0)$ & $10.0(1.4-27.4)$ & 0.14 & 0.0479 \\
Temperate, humid & $8.4(1.9-21.2)$ & $11.9(5.2-26.2)$ & 0.05 & 0.4686 \\
Tropical, dry & $6.0(1.7-12.8)$ & $7.6(2.5-16.7)$ & 0.07 & 0.3427 \\
Tropical, humid & $11.2(2.5-28.7)$ & $7.9(3.7-16.0)$ & 0.13 & 0.0504 \\
\hline
\end{tabular}

with cover crop resulting in the largest decline. Cover crops and no-residue removal had opposite effects on both yields and $\mathrm{N}$ leaching. The reduction in $\mathrm{N}$ leaching from cover crops $(\sim 15 \%)$ was accompanied by a decline in simulated global yields of $5 \%$. The large negative effect of cover crops on simulated yields in the temperate humid climatic region is due to the implicit competition for the available $\mathrm{N}$ between the cover crop and the main crop; the low temperature makes the decomposition of the SOM slow and, in turn, the release of $\mathrm{N}$ more evenly spread throughout the year. The $\mathrm{N}$ retained in the system is locked into SOM and not easily available for plant uptake; the opposite happens in the tropical regions and especially so for the humid tropics, where turnover of the SOM is relatively fast due to the prevailing warm and 


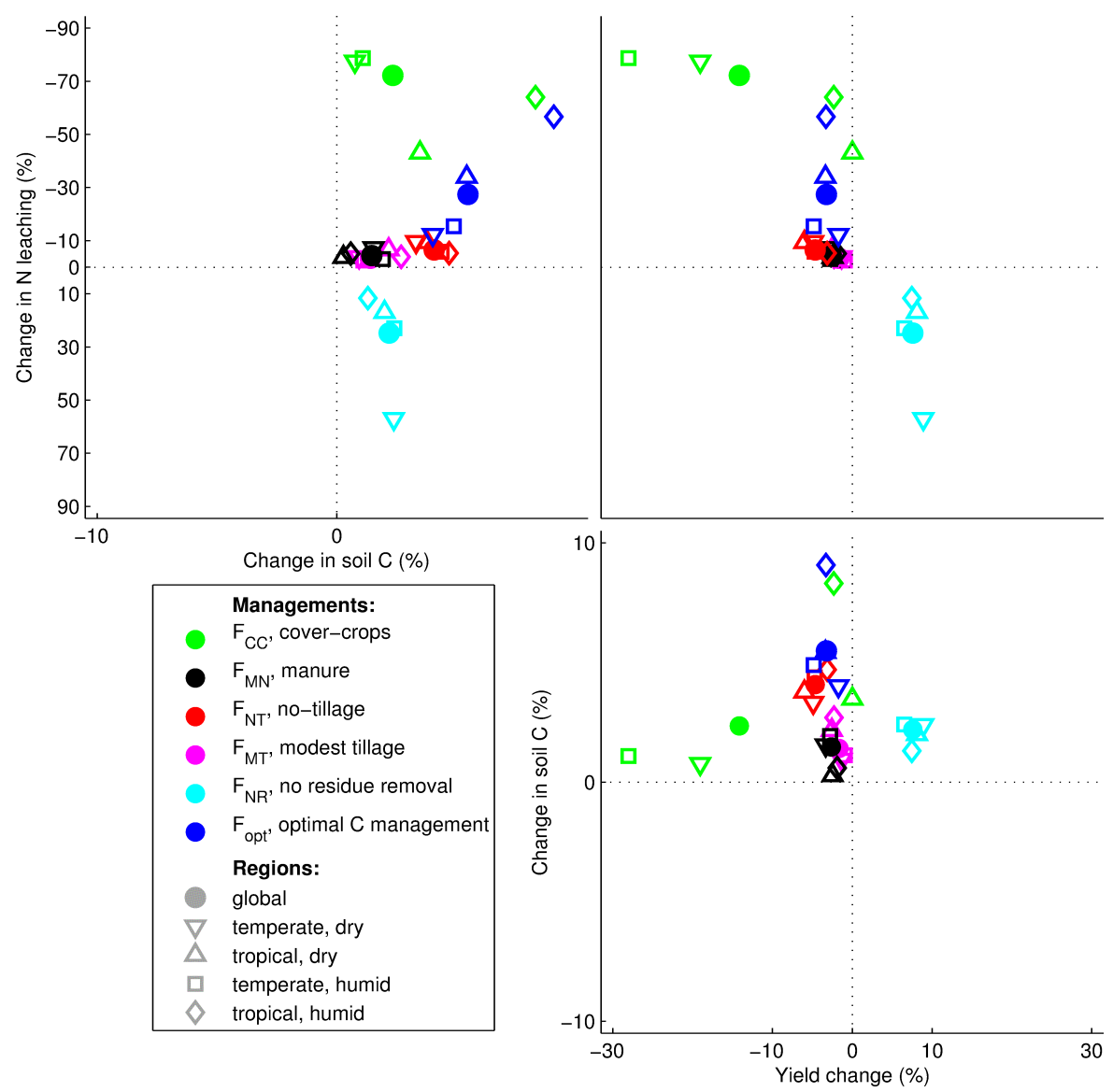

Figure 3. The simulated relative response (\%) of soil carbon to management options (Table 2) compared to the standard set-up, averaged for 1996-2005 and displayed as the global response (filled symbol) and per climatic region. Note the reversed axes for N leaching (all axes display scales from reduced to enhanced ecosystem services with the upper right corner representing a win-win situation).

moist conditions. Leaving all the residues on the fields (no residue removal) was the only treatment that increased the modelled yields both globally and for all climatic regions but with the environmental "cost" of an increase in $\mathrm{N}$ leaching. The increase in both modelled yields and $\mathrm{N}$ leaching is obtained because $\mathrm{N}$ becomes available for plant uptake and transport over a longer period, and nothing grows between the growing periods that can take up the available nitrogen. In all treatments, the soil $\mathrm{N}$ pools were higher than for the standard simulation (Table 3), which is caused by the reduction in leaching and the incorporation of nitrogen in SOM.

In general, the soil $\mathrm{C}$ pools simulated with the managed land version of LPJ-GUESS were slightly larger than simulated with PNV (Table 4), which is due to higher C storage in pastures compared to the natural vegetation which the pastures have replaced (e.g. central Asia and parts of the Great Plains of North America) and also in high-productivity croplands that receive high inputs of $\mathrm{N}$ fertilisers (e.g. Egypt and western China; results not shown here).

From the simulations of different cropland management options, the management combination that yielded the largest
SOC stocks for the period 1996-2005 was chosen for each grid cell $\left(F_{\mathrm{opt}}\right)$; the spatial patterns are shown in Fig. 4, with cover crop and no-till management being the most dominant and with distinct differences with cover crop mostly in humid tropical areas and no-till management in subtropical and temperate regions.

For the future simulations, there were changes in the optimal $\mathrm{C}$ sequestration management (Table 5), most of these "transitions" ( $\sim 7 \%$ for RCP2.6 and $\sim 9 \%$ for 8.5$)$ being from no-till management to the other management type options (Fig. 6).

Figure 5 depicts the evolution over time of the effects of implementing the different soil carbon sequestration management types for two future climate change, $\mathrm{CO}_{2}$ and landuse change scenarios. The spread that can be seen around the simulations with CRU forcing in Fig. 5 originates from the GCM climate variability, which can be seen also during the historic period (Fig. A1b). In the scenarios of landuse change (Hurtt et al., 2011), there is a steady increase in cropland area globally, which is most extreme for RCP2.6 (Fig. A1a). Differences between the RCP2.6 and 8.5 cases 
Table 4. Modelled global, total land and cropland soil $\mathrm{C}$ and $\mathrm{N}$ stocks and total $\mathrm{N}$ leaching (inorganic and organic) for the time period 1996-2005, compared to estimates from the literature. References for the studies and explanations of how some of the values were derived can be found in the notes of this table. See Table 2 for abbreviations.

\begin{tabular}{|c|c|c|c|c|c|c|}
\hline \multirow[b]{2}{*}{ Model } & \multicolumn{2}{|c|}{ Soil C, total (Pg C) } & \multicolumn{2}{|c|}{ Soil N, total $(\operatorname{Pg} N)$} & \multicolumn{2}{|c|}{$\mathrm{N}$ leach $\left(\mathrm{Tg} \mathrm{N} \mathrm{yr}^{-1}\right)$} \\
\hline & Global $^{\mathrm{a}}$ & Cropland & Global $^{\text {b }}$ & Cropland & Global & Cropland \\
\hline$F_{\text {std }}$ & 1440 & 148 & 146 & 16 & 55 & 44 \\
\hline$F_{\mathrm{CC}}$ & 1444 & 151 & 146 & 16 & 24 & 12 \\
\hline$F_{\mathrm{MT}}$ & 1442 & 150 & 146 & 16 & 54 & 42 \\
\hline$F_{\mathrm{NT}}$ & 1447 & 154 & 146 & 17 & 53 & 41 \\
\hline$F_{\mathrm{MN}}$ & 1442 & 150 & 146 & 16 & 54 & 42 \\
\hline$F_{\mathrm{NR}}$ & 1443 & 151 & 146 & 16 & 66 & 54 \\
\hline$F_{\mathrm{PNV}}$ & 1385 & & 139 & & 18 & \\
\hline Other & $1993-2456^{\mathrm{c}}$ & $171^{\mathrm{e}}$ & $133-140^{\mathrm{f}}$ & & $50^{\mathrm{g}}$ & $14-24^{\mathrm{i}}$ \\
\hline studies & $1500-2400^{\mathrm{d}}$ & & & & $80^{\mathrm{h}}$ & $23^{\mathrm{j}}$ \\
\hline
\end{tabular}

a These numbers do not include litter; soil C including litter is 1668 and $1671 \mathrm{Pg} \mathrm{C}$ for $F_{\text {std }}$ and $F_{\mathrm{PNV}}$ respectively.

b These numbers do not include litter; soil $\mathrm{N}$ including litter is 147 and $140 \mathrm{Pg} \mathrm{N}$ for $F_{\text {std }}$ and $F_{\mathrm{PNV}}$ respectively.

${ }^{\mathrm{c}}$ Stockmann et al. (2013). ${ }^{\mathrm{d}}$ Ciais et al. (2013). ${ }^{\mathrm{e}}$ Stockmann et al. (2013); the estimate for 0-2 $\mathrm{m}$ is $184 \mathrm{Pg} \mathrm{C}$, and that for $0-1 \mathrm{~m}$ is $157 \mathrm{PgC} .{ }^{\mathrm{f}}$ Batjes (2014). ${ }^{\mathrm{g}}$ Estimated from Fig. 4 in Boyer et al. (2006): $39-60 \mathrm{Tg} \mathrm{N} \mathrm{yr}^{-1}$. ${ }^{\mathrm{h}}$ Gruber and Galloway (2008). ${ }^{\mathrm{i}}$ Smil (1999). ${ }^{\mathrm{j}}$ Liu et al. (2010).

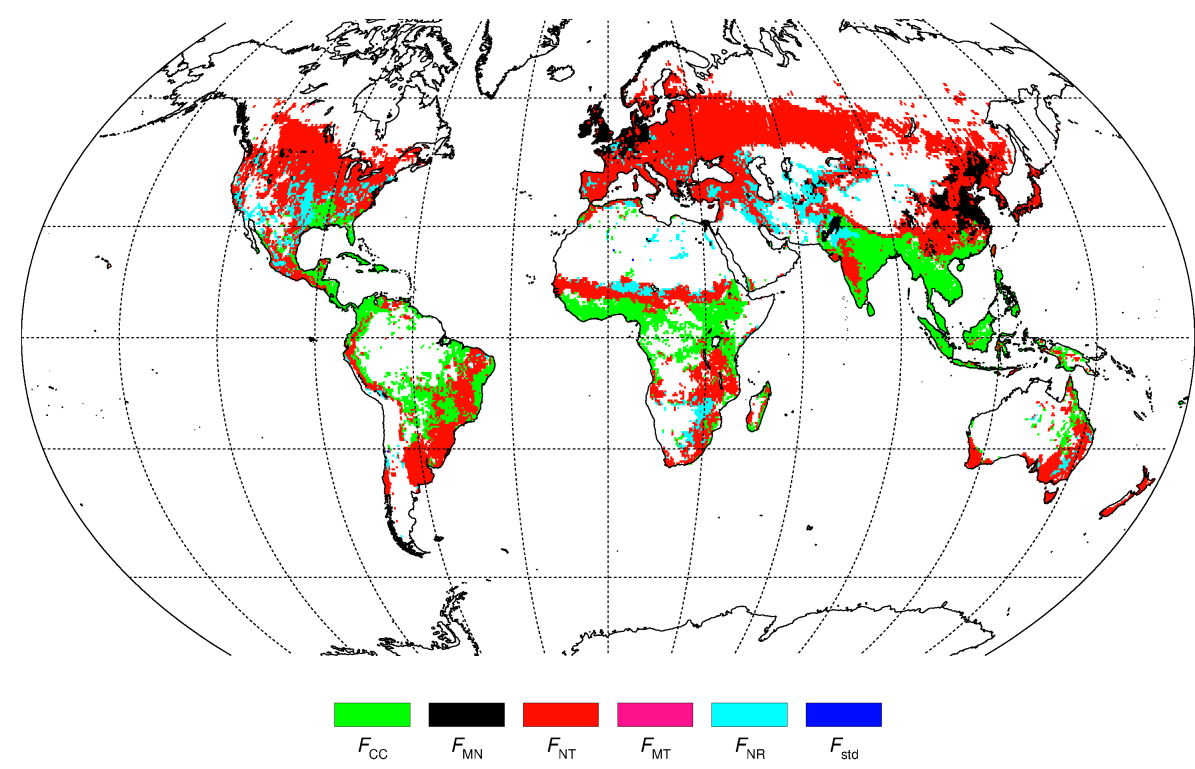

Figure 4. Optimal carbon sequestration practice $\left(F_{\mathrm{opt}}\right)$ around the year 2000, as simulated by LPJ-GUESS, based on the different management practices and trade-offs shown in Fig. 3 (see also Table 2 for the abbreviations). The standard set-up ( $F_{\text {std }}$, blue) was selected when none of the other management types gave an increase in the amount of carbon sequestered. The $\mathrm{C}$ sequestered compared to $F_{\text {std }}$ for choosing the optimal practice in each grid cell is $7.7 \mathrm{Pg} \mathrm{C}$ from 1750 to 2000 ; the reduction in global $\mathrm{N}$ leaching for best $\mathrm{C}$ sequestration practices is $11.9 \mathrm{Tg} \mathrm{N} \mathrm{yr}^{-1}$.

regarding the effects of management are consistently seen only for cropland soil C storage, with values being higher for RCP8.5 than for RCP2.6. Manure and no-tillage did not affect calculated $\mathrm{N}$ leaching or yields under future conditions any more than for present-day forcing. The effect of cover crops and best carbon management for RCP8.5 was an enhanced reduction in yields and enhanced $\mathrm{N}$ leaching compared to the standard model set-up.

\section{Discussion}

Olin et al. (2015) addressed the effect of N-fertiliser applications on crop yields in Europe. In the present study we extended this analysis to the global scale and addressed the effect of additional land-management practices, other than fertiliser applications, on crop yields and carbon retention in cropland ecosystems and soils. The management practices 


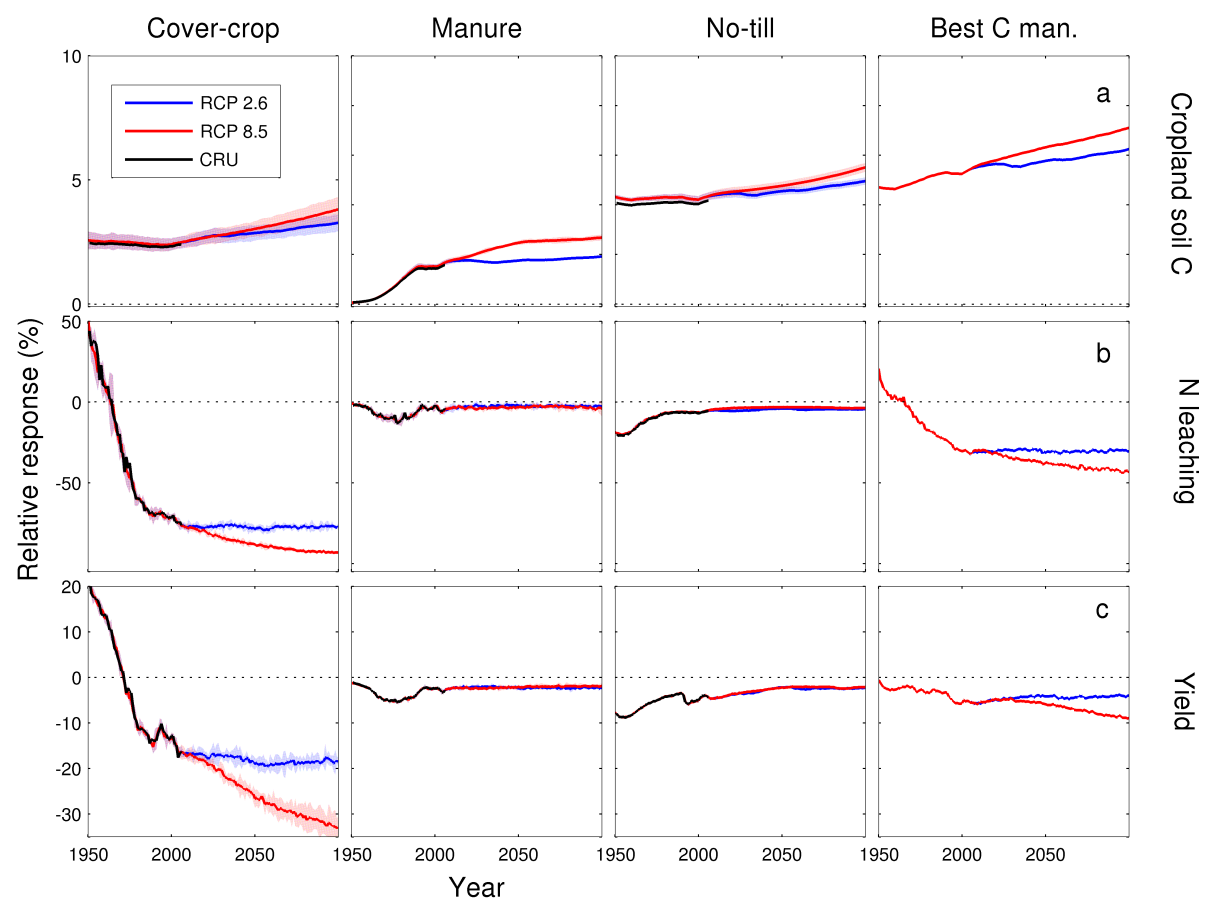

Figure 5. The simulated response on (a) global $\mathrm{C}$ in cropland soils, (b) yields and (c) $\mathrm{N}$ leaching with management options implemented in LPJ-GUESS relative to the standard set-up. The black line represents the response with historic climate (CRU); red and blue show the mean of simulations using four GCMs (described in Sect. 2.2) for RCPs2.6 and 8.5 respectively. Shaded areas show the mean \pm 2 SD. The panels on the right show the results from choosing the best SOC management compared to the standard for the two RCPs.

explored are widely used approaches that have been recommended as suitable for climate change mitigation and are claimed to have benefits for a range of ecosystem services.

\subsection{Soil carbon and nitrogen}

LPJ-GUESS projections of soil $\mathrm{N}$ pools agree well with other estimates, although the soil $\mathrm{C}$ pools are at the low end of generally reported global estimates (Ciais et al., 2013; Stockmann et al., 2013). This is to be expected since, for instance, the present version of the model does not include wetland and permafrost processes (Miller and Smith, 2012; Tarnocai et al., 2009; Wania et al., 2009). The accurate modelling of soil carbon pool sizes and changes is of great importance when assessing impacts of global environmental change, since soils are the main long-term terrestrial sink of carbon (Smith, 2004a). While DVMs and Earth system models still do not capture all processes that are known to be important (McGuire et al., 2001; Sitch et al., 2008), an additional complication arises also from the limited availability of observational soil carbon data. Global estimates of soil carbon and nitrogen pools are derived by extrapolation of highly variable point observations from soil inventories or from data-based modelling. For instance, global $\mathrm{C}$ and $\mathrm{N}$ densities reported by Batjes (2014) (see Table 4) were derived by extrapolating measurements taken in 4353 soil cores across all biomes, using maps of soil types and land cover.
When making projections on global $\mathrm{C}$ pools, the information on land-use history is vital (Pongratz et al., 2014). In our simulations, the assumption that the main - natural to cropland - conversions started in 1750 could have resulted in overestimations of $\mathrm{C}$ stored in agricultural soils where agriculture has been practised for a long time but, conversely, in underestimations of soil $\mathrm{C}$ storage in areas where agriculture is only a recent feature. We expect this effect to be most profound in areas where agriculture has been practised for many centuries such as the Middle East, India and central Europe. The result that the simulations with cropland and pastures showed a higher global soil C pool than the PNV simulation (Table 4) can be explained by a higher productivity than the PNV they replaced, e.g. croplands in Egypt (due to irrigation and high $\mathrm{N}$ input) and major pasture areas, e.g. in Mongolia; this is consistent with observations (Guo and Gifford, 2002).

When focusing on site data collected for croplands and grouped by four climate regions (Table 3 ), simulated average $\mathrm{C}$ pools in LPJ-GUESS were higher than observations, especially for temperate soils. It is to be expected that many of these sites, especially in temperate environments, would have been under land use for very long periods, which could well lead to lower $\mathrm{C}$ pools compared to our modelling assumptions. However, we do not have comprehensive information on present management practices or on how these would have changed over time, and we are therefore unable to draw definitive conclusions. Still, the among-grid-cell variations in 


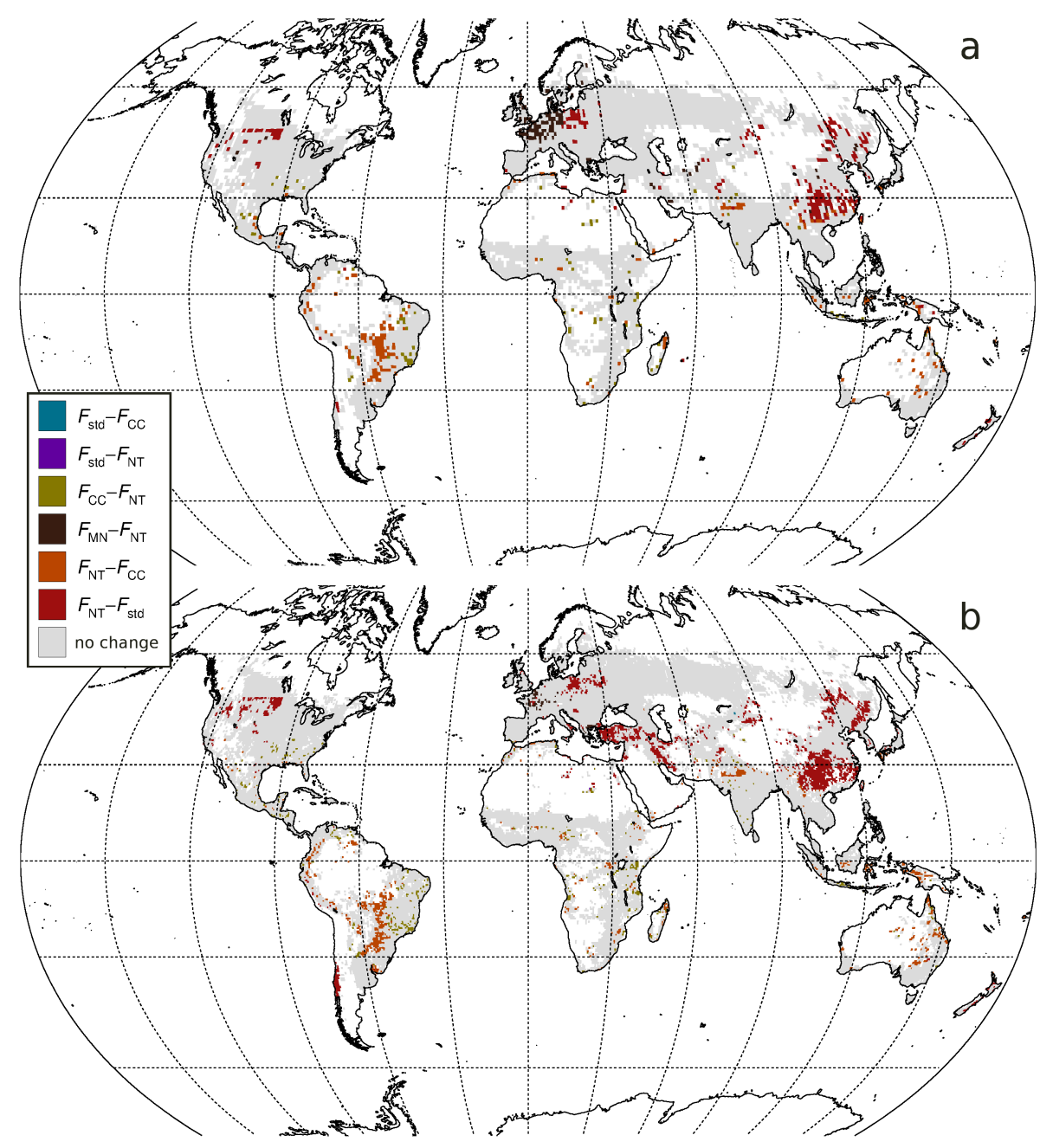

Figure 6. Grid cells where different management options resulted in the highest soil carbon in 2000 (Fig. 4) compared to 2050 : (a) RCP2.6 and (b) 8.5. Grid cells with no cropland in the input data set are shown in white.

C pools were similarly large in observed and simulated data (Table 3), suggesting that the model response to environmental and management perturbations is realistic.

\section{Carbon sequestration potential through cropland management}

Global-scale modelling of the impacts of specific landmanagement options is in its infancy, but since a number of future climate and socioeconomic scenarios highlight the importance of land-based mitigation and because of the multiple trade-offs that exist with other ecosystem services, they are of importance for future research and practical applications.

In the comparison with potential $\mathrm{C}$ sequestration (Fig. 2), the mean modelled response with 2 standard deviations was either below or in the lower range of the published values from Stockmann et al. (2013). One possible reason for the discrepancy between the modelled $\mathrm{C}$ sequestration rate and that from Stockmann et al. (2013) could be that the number of sites and the spread over geographic regions - neither of which are specified in that study - are larger in our simulated estimates. For tropical soils, as discussed in more detail below, the overestimation of $\mathrm{C}$ sequestration could be linked to the higher productivity with the cover-crop management. Published estimates of the carbon sequestration potential on existing cropland due to different types of cropland management range between $0.34-0.57 \mathrm{Pg} \mathrm{C} \mathrm{yr}^{-1}$ for present-day environmental conditions (Lal, 2004b). Globally, our model estimate when implementing the best practice (from the perspective of maximising C storage) is roughly $20 \%$ of that value. Figure 3 shows a global increase of ca. $5 \%$ in soil $\mathrm{C}$ for the $F_{\text {opt }}$ case (ranging from 4 to $9 \%$ between large regions), which equates to an annual uptake of $0.08 \mathrm{Pg} \mathrm{C} \mathrm{yr}^{-1}$ globally compared to the standard model version. The exact reasons for these low simulated uptake rates are difficult to assess, but representing land-use history and landmanagement practices on a large regional to global scale is a 
Table 5. The relative (\%) number of cropland grid cells with a shift regarding the management practice optimal from a carbon sequestration perspective, comparing the highest SOC for 1996-2005 and for 2046-2055 for RCP2.6 and 8.5. Also listed are the share of the cropland grid cells with no change in the optimal $\mathrm{C}$ sequestration practice and the percentage of the total number of grid cells that were cropland around the year 2000 in the data set from Hurtt et al. (2011). See Table 2 for abbreviations.

\begin{tabular}{llcc}
\hline & & \multicolumn{2}{c}{ Amount of grid cells $(\%)$} \\
\cline { 3 - 4 } From & To & RCP2.6 & RCP8.5 \\
\hline$F_{\text {std }}$ & $F_{\mathrm{CC}}$ & 0.7 & 0.7 \\
$F_{\text {std }}$ & $F_{\mathrm{MN}}$ & 0.2 & 0.3 \\
$F_{\text {std }}$ & $F_{\mathrm{NT}}$ & 1.0 & 0.9 \\
$F_{\mathrm{CC}}$ & $F_{\text {std }}$ & 0.2 & 0.1 \\
$F_{\mathrm{CC}}$ & $F_{\mathrm{MN}}$ & 0.3 & 0.5 \\
$F_{\mathrm{CC}}$ & $F_{\mathrm{NT}}$ & 2.2 & 2.5 \\
$F_{\mathrm{MN}}$ & $F_{\mathrm{std}}$ & 0.0 & 0.0 \\
$F_{\mathrm{MN}}$ & $F_{\mathrm{CC}}$ & 0.1 & 0.1 \\
$F_{\mathrm{MN}}$ & $F_{\mathrm{NT}}$ & 1.3 & 0.4 \\
$F_{\mathrm{NT}}$ & $F_{\text {std }}$ & 0.2 & 0.1 \\
$F_{\mathrm{NT}}$ & $F_{\mathrm{CC}}$ & 3.8 & 3.5 \\
$F_{\mathrm{NT}}$ & $F_{\mathrm{MN}}$ & 2.9 & 5.2 \\
\hline \multicolumn{2}{c}{ No change } & 87.2 & 85.6 \\
Cropland cells & 69.1 & 67.2 \\
\hline
\end{tabular}

recognised challenge. In the CLM (Community Land Model) (Levis et al., 2014), country-specific tillage management has been implemented, which is not constant over the year but carried out in connection with harvest. The authors found that CLM without accounting for tillage practices underestimates the emissions caused by agricultural practices. Unfortunately, due to the different set-up of our simulations, it is not possible to compare numbers directly between our studies. Levis et al. (2014) modelled the effect of a sudden global introduction of tillage, effectively condensing decades or centuries of emissions into a 30-year period. However, if the $0.4 \mathrm{PgC} \mathrm{yr}^{-1}$ of Levis et al. (2014) were distributed over a 250 -year period, equivalent to the $1750-2006$ treatment of land use in our simulations, the $0.05 \mathrm{Pg} \mathrm{C} \mathrm{yr}^{-1}$ thus derived would be comparable to the estimate in our study of $0.02 \mathrm{Pg} \mathrm{C} \mathrm{yr}^{-1}\left(F_{\mathrm{NT}}-F_{\text {std }}\right)$. We have chosen to implement uniform management for tillage in this study, reasoning that the additional assumptions one would need to make to resolve spatially varying tillage would increase the uncertainty in our model predictions, in particular because of the absence of available information on future tillage practices.

Another important aspect is productivity during the growing season and the possibility of multicropping. In many tropical areas the growing season is not limited to a short period of the year, especially in the humid tropics where two or more crops may be grown in sequence (Francis, 1989). Currently LPJ-GUESS is restricted to one growing period per year for the primary crop. Multiple cropping has been im- plemented in other modelling frameworks, such as LPJmL (Lund-Potsdam-Jena managed Land)(Waha et al., 2013). Multiple cropping does not always increase the yields of the economic crops but results in a more resilient cropping system with more than one harvest per year and thus reduces the risk of complete crop failures, while promoting high net productivity (Francis, 1989); it is thus also relevant to consider it from a carbon cycle perspective. Thus, the simplifications we necessarily have to include in a global model regarding some management applications might lead to overall lower $\mathrm{C}$ sequestration compared to other published estimates (Lal, 2004a; Smith, 2004b). However, it also needs to be noted that these previous estimates are based on empirical modelling, not accounting for process-level interactions between vegetation, soils and the abiotic environment. In a review of the potential for countries to fulfil emissions reduction obligations under the Kyoto protocol (IPCC, 1996), Schlesinger (2000) found only a small or no potential for C sequestration in cropland soils, while Powlson et al. (2014) argued that no-tillage management following tillage enhances some important soil properties but has a small overall effect on total agricultural soil C.

\subsection{Yields}

Compared to other measures of global C flows, statistics on crop production and yields are relatively accessible and encompass relatively long time series, albeit with differing qualities between individual countries. While yield is not a direct measure of the net primary productivity (NPP), it is a good proxy for trends and variability in carbon flows on croplands (Haberl et al., 2007) and thus relevant for the estimation of fluxes and pools in agricultural fields. From a food production perspective, Olin et al. (2015) showed that including $\mathrm{C}-\mathrm{N}$ dynamics and fertiliser input significantly increased model performance compared to the C-only version of LPJGUESS (e.g. Rosenzweig et al., 2014) for yield modelling and responses of yields to environmental changes. This was expected, since the C-only version intentionally represents a situation not limited by spatial or temporal variations in nutrient availability. The data sets used in this study were either designed for crop modelling in the AgMIP (Agricultural Model Intercomparison and Improvement Project) (Elliott et al., 2014) or for studying global flows of carbon and nitrogen (rather than yields) (Stocker et al., 2013; Zaehle et al., 2011). When using the former, Elliott et al. (2014), the model performance was significantly improved (an increase in model agreement $\left(R^{2}\right)$ with observed yields from 0.25 to 0.53 for WW and from 0.1 to 0.25 for MA). However, since the AgMIP data set lacks information on temporal variations and trends, it could not be applied to transient historical or future simulations of global yields, $\mathrm{C}$ and $\mathrm{N}$ flows. Previous global modelling studies incorporating $\mathrm{C}-\mathrm{N}$ dynamics have reported correlations of simulated yield with FAO statistics of $R^{2}=0.22\left(\mathrm{WW}\right.$ ) and $R^{2}=0.39$ (MA) for PE- 
GASUS (Predicting Ecosystem Goods And Services Using Scenarios) (Deryng et al., 2011) and $R^{2}=0.66(\mathrm{WW})$ and $R^{2}=0.67$ (MA) for DayCent (Daily Century) (Stehfest et al., 2007).

Our results compare favourably with these studies for WW but less so for MA. The $\mathrm{C}-\mathrm{N}$ version of our model has not yet been evaluated and parameterised against observations of maize yields, and the lower degree of agreement with data was expected.

We also compared historical global crop yields with numbers found in FAOSTAT. Yields in the early 1960s were similar (ca. $1.5 \mathrm{tha}^{-1} \mathrm{yr}^{-1}$ ), but increases in yields were faster in the reported statistics compared to the model output. Whether or not this related to a missing process in yield simulations (e.g. lack of double cropping; Waha et al., 2013) or uncertainty in the fertiliser hindcast product used needs to be explored in future work.

The modelling approach taken here to represent all crops globally with three CFTs introduces an uncertainty into the estimates of global food production and thus also into the carbon cycle. We expect that this would be most prominent for crops whose growing seasons, water requirements, or physiology differ substantially from the functional types used here, e.g. regions where rice (south-east Asia) or tubers (Africa) are grown over a large section of harvested area. In many rice-producing regions, a second growing season is often present each year (Waha et al., 2013), whereas in the model the number of seasons is limited to one, although the use of cover crops is expected to decrease the effect of this limitation on the carbon cycle simulations.

\subsection{N leaching}

Global estimates of $\mathrm{N}$ leaching from terrestrial ecosystems are uncertain (Gruber and Galloway, 2008), and the estimates with LPJ-GUESS fall well within the broad range of published annual global totals (Table 4). Only a few other global studies with DVMs (e.g. Smith et al., 2014; Stocker et al., 2013; Yang et al., 2009; Zaehle et al., 2010b) have reported $\mathrm{N}$ leached from terrestrial ecosystems. For models that included $\mathrm{N}$-fertiliser applications, we estimated a range from $63 \mathrm{Tg} \mathrm{Nyr}^{-1}$ (Yang et al., 2009) to $133 \mathrm{Tg} \mathrm{Nyr}^{-1}$ (Stocker et al., 2013) . None of these simulation studies accounted for croplands explicitly; nonharvested grasslands in Zaehle et al. (2010b) and harvested grasslands in Stocker et al. (2013) were used as proxies for croplands. Zaehle et al. (2010b), estimated the total N leached to aquatic ecosystems from terrestrial sources to be $86 \mathrm{Tg} \mathrm{N} \mathrm{yr}^{-1}$, of which $57 \mathrm{Tg} \mathrm{N} \mathrm{yr}^{-1}$ was attributed to agri-

\footnotetext{
${ }^{3}$ Derived by scaling their average $0.47 \mathrm{~g} \mathrm{~N} \mathrm{~m}^{-2} \mathrm{yr}^{-1}$ by the icefree land area of $1.33 \times 10^{14} \mathrm{~m}^{2}$; this is consistent with the estimates elsewhere in this study.

${ }^{4}$ Derived from the leaching-associated $\mathrm{N}_{2} \mathrm{O}$ emissions of $0.8 \mathrm{Tg} \mathrm{Nyr}^{-1}$ equalling to a the constant fraction of $0.6 \%$ of leached nitrogen
}

cultural ecosystems. These estimates for the entire land surface are considerably larger than the estimates provided here (24-66 $\mathrm{Tg} \mathrm{N} \mathrm{yr}^{-1}$ for the simulations including croplands; Table 4). Among the simulations performed here, the simulation without residue removal $\left(F_{\mathrm{NR}}\right)$ was the only one in which $\mathrm{N}$ leached from croplands was of comparable magnitude to the findings of Zaehle et al. (2010b). In our study fertilisers are applied at specific crop developmental stages with amounts that match the CFT-specific demand (see Table A2), whereas in Zaehle et al. (2010b) three applications with equal amounts were spread using climate indicators defining the peak in the growing season. This could lead to higher leaching when fertiliser application is not timed to coincide with the peak of the growing season, when crop $\mathrm{N}$ uptake is highest. Despite its importance for the overall amount of leached N (Cameron et al., 2013), the timing of fertiliser applications alone cannot explain the difference between this study and Zaehle et al. (2010b). By contrast to the three other DVM studies mentioned above, LPJ-GUESS treats all inorganic $\mathrm{N}$ as one pool, as opposed to modelling nitrate and ammonium separately. A fraction of this pool is leached without any distinction of the nitrogen species, while, in reality, most of the nitrogen leached is in the form of nitrate (Smil, 1999 ) and only a small amount is in the form of organic $\mathrm{N}$ or ammonium, the latter mainly in association with extreme events like floods. During the growing season when crops (and plants in general) are active, leaching may thus be expected to be overestimated by our model as nitrates are the primary nitrogen source for plants (Penning de Vries et al., 1989), while during the fallow periods with no or only very little vegetation cover - and consequently a relatively higher abundance of nitrates than of ammonium - the nitrogen exported in conjunction with run-off and drainage will tend to be underestimated.

\subsection{Trade-offs and win-win management options}

Due to the rising human population, changing lifestyles, as well as a number of - sometimes conflicting - policies related to, e.g., climate change mitigation, agriculture, conservation or water regulation, the demand for resources from land ecosystems is increasing and also constantly changing. In order to achieve, ultimately, a sustainable use of natural resources, there is a need to identify strategies that minimise degradation and wastage of resources while still addressing society's growing needs for land-based ecosystem services including agricultural production. To this end, information on the trade-offs implicit in different management strategies but also possible win-win situations is of high value. In our analysis we attempted to compare three important parameters related to ecosystem functioning (yield, $\mathrm{C}$ uptake and $\mathrm{N}$ leaching) in terms of how different forms of crop management may be expected to influence their relative patterns of change. From our results (Fig. 3), two general findings emerge. Firstly, none of the management options explored 
lead to a win-win situation in the sense of an increase in all three of the examined variables. Secondly, general patterns of change on the global scale were - with some variability - also seen on the regional scale: we did not (for presentday conditions) find a situation where a win-win situation on the global scale was contingent upon trade-offs on a large regional scale.

All the implemented management options targeting carbon benefits resulted in a net increase in simulated soil carbon (Fig. 3). Most of these also showed the added benefit of reduced leaching of $\mathrm{N}$ - albeit at the cost of reduced yields. Avoiding residue removal stands out from this general pattern, resulting in increased soil $\mathrm{C}$ and increased yields but at the same time enhanced $\mathrm{N}$ leaching. The largest effects, at least when taking the regional spread into consideration, were found when including cover crops as a management option. The relatively large reduction in yield found in the $F_{\text {CC }}$ simulations resulted from indirect competition for water and nitrogen, which were not available for the new crops planted following the cover-crop period. Interestingly, even though the yields were substantially lower in $F_{\mathrm{CC}}$, the total vegetation productivity was higher due to the extended growing period (not shown; global annual total NPP was $+0.25 \mathrm{PgC} \mathrm{yr}^{-1}$ larger for $F_{\mathrm{CC}}$ compared to that of $F_{\mathrm{std}}$ ). This higher NPP was also reflected in the enhanced soil C content. In reality, cover crops are an oft-applied management technique to sequester or retain nutrients and carbon in the field, which is why legumes are a preferred choice. While LPJ-GUESS correctly simulates enhanced C sequestration with cover crops, symbiotic $\mathrm{N}$ fixation is not yet implemented in the current crop version of the model. Hence, the indirect competition for $\mathrm{N}$ between cover crop and main crop discussed above may be overestimated in the model. Vegetation carbon and nitrogen turnover in the grass PFT used here for $F_{\mathrm{CC}}$ obviously is too slow to make nitrogen available for the following crops, in particular in the temperate regions, which could also underlie the strong simulated reduction in leaching.

Absence of residue removal was positive for soil carbon as well as for yields because of the higher litter input. Similar responses of enhanced $\mathrm{C}$ storage (up to $30 \%$ ) and increased yields (10-30\%) to residue management have also been found for, e.g., maize and soybean in the US (Wilhelm et al., 2004) and millet in Niger (Bationo et al., 1993).

Manure $\left(F_{\mathrm{MN}}\right)$ application had minor effects on all the investigated processes, both globally and with regard to particular climatic regions (Fig. 3). The relatively low effect on soil $\mathrm{C}$ might be caused by the relatively small fraction of the total $\mathrm{N}$ applied at sowing (which is the time when manure was also applied): $8 \%$ for WW and $11 \%$ for SW and MA. In terms of yield, the relatively high $\mathrm{C}: \mathrm{N}$ (30) might have reduced crop productivity slightly, since the manure $\mathrm{N}$ will not be available for plant uptake at sowing but will be released from the SOM during the growing season. Still, in some of the highly productive regions (e.g. north-western Europe and parts of China), manure application was the most effective management for carbon sequestration (Fig. 4); these are all areas where the $\mathrm{N}$ application rates in the data set used here are high (Zaehle et al., 2011), and thus the amount of carbon added to the soil is relatively large.

By contrast with moderate tillage, complete absence of tillage resulted in enhanced soil $\mathrm{C}$, with only small to moderate yield reduction and a small reduction in $\mathrm{N}$ loss through leaching. Depending on the regional climate and $\mathrm{N}$-fertiliser applications, reductions in crop productivity by up to $0.5 \mathrm{tha}^{-1}$ were also reported for maize and winter wheat grown in the USA in a recent meta-analysis, comparing tillage to no-tillage (Ogle et al., 2012). A larger effect on $\mathrm{C}$ sequestration (at similarly small to moderate effects on yields) was only found when optimising for carbon sequestration also resulted in a moderate reduction in yields while achieving a reduction in the modelled $\mathrm{N}$ leaching by ca. $30 \%$ (Fig. 3). Considering the high global demand for food today and in the future, it may be difficult to convince producers that a $5 \%$ yield reduction is worth a $5 \%$ increase in soil $\mathrm{C}$ and reduced leaching. Avoiding the loss of food production would require either further intensification (likely resulting in enhanced $\mathrm{N}$ losses through leaching) or the expansion of crop and pasture areas (potentially interfering with other ecosystem services). In this regard, it is crucial to consider regional differences. Large vegetation carbon stocks in tropical forest ecosystems motivate the protection of these systems, limiting the further expansion of managed land in these ecosystems. Given that tropical areas tend also to have the largest yield gaps (Licker et al., 2010), a much better strategy in these regions is to invest in sustainable intensification of existing managed land.

The initial difference between $F_{\text {opt }}$ and $F_{\mathrm{CC}}$ in Fig. 3, where $F_{\mathrm{CC}}$ had a positive effect on yields until the mid 1960 s, is due to the fact that in the model, the cover crops are being sown with a finite initial carbon and nitrogen mass. This results in more available nitrogen in the fields with this management (basically a fertilisation via the seeds), despite the indirect competition for nitrogen between the cover crop and the main crop, which subsequently also results in a relatively larger nitrogen export through leaching. Cover crops have been used to revitalise croplands; the result shown here implies that the model partly captures this, but the simulated indirect competition is too strong and further studies and model developments are needed to better represent cover-crop management. Also, as the cover-crop implementation does not include symbiotic $\mathrm{N}$ fixation, the simulated reduction in yields with that management could very well have resulted in the opposite effect but, as was seen for $\mathrm{N}$ leaching prior to 1960 and also for the no-residue removal, maybe also in a relative increase in the $\mathrm{N}$ leakage. 


\section{Conclusions}

We have presented a global model analysis highlighting effects of alternative crop management strategies for a range of core ecosystem processes and the services derived from them, related to interactions of climate change and land-use change.

Our large-scale approach based on the simplifying assumption of uniform management across regions does not faithfully represent actual conditions but instead allows the influence of different management actions to be evaluated and geographical differences to be highlighted. The model is equipped to perform simulations with more detailed (country-scale or regional) management, and it can thus be used in applications addressing questions of the environmental impact from, for instance, policies or trends relating to agricultural intensification or extensification or climate mitigation.
Results demonstrate that the effects of management on cropland can be beneficial for carbon and nutrient retention without risking (large) yield losses. Nevertheless, effects on soil carbon are small compared with extant stocks in natural and semi-natural ecosystem types and managed forests. While agricultural management can be targeted towards sustainable goals, from a climate change or carbon sink perspective avoiding deforestation or reforestation constitutes a far more effective overall strategy for maintaining and enhancing global carbon sinks. However, enhanced carbon storage in agricultural soils could also be seen as a surrogate for enhanced soil structure and reduced erosion having additional (non-climate) environmental benefits. 


\section{Appendix A: Allocation}

In Olin et al. (2015) relationships between allocation to leaves $\left(g_{\mathrm{L}}\right)$, stem $\left(g_{\mathrm{St}}\right)$, root $\left(g_{\mathrm{R}}\right)$ and grains $\left(g_{Y}\right)$ based on the allocation model of Penning de Vries et al. (1989) were established using a logistic growth function, a Richards curve (Richards, 1959) (Eq. A1):

$f_{i}=a+\frac{b-a}{1+e^{-c(\mathrm{DS}-d)}}$,

where $f_{i}$ is the daily allocation of assimilates to a plant organ relative to, e.g., the shoot, $a$ is the asymptote when DS $\rightarrow 0$, $b$ is the upper asymptote when DS $\rightarrow \infty, c$ is the growth rate, and $d$ is the DS of maximum growth.

The relative relationships of daily assimilate allocation to the organs are described by Eq. (A1):

$f_{1}=\frac{g_{\mathrm{R}}}{g_{\mathrm{R}}+g_{\mathrm{L}}+g_{\mathrm{St}}}, f_{2}=\frac{g_{\mathrm{L}}}{g_{\mathrm{L}}+g_{\mathrm{St}}}, f_{3}=\frac{g_{Y}}{g_{\mathrm{R}}+g_{\mathrm{L}}+g_{\mathrm{St}}+g_{Y}}$.

Combining the equations in Eq. (A2) yields

$g_{\mathrm{R}}=f_{1}\left(1-f_{3}\right)$

$g_{\mathrm{L}}=f_{2}\left(1-f_{1}\right)\left(1-f_{3}\right)$

$g_{\mathrm{St}}=\left(1-f_{2}\right)\left(1-f_{1}\right)\left(1-f_{3}\right)$

$g_{Y}=f_{3}$.

See Olin et al. (2015) for more details on how these relationships were derived.
Table A1. The parameters for the factors $f_{1}, f_{2}$ and $f_{3}$ in the carbon allocation scheme (Eq. A2) for spring wheat (SW), winter wheat (WW) and maize (MA).

\begin{tabular}{rrrrr}
\hline \multicolumn{2}{l}{ Parameter } & SW & WW & MA \\
\hline$f_{1}:$ & $\mathrm{a}$ & 0.62 & 0.53 & 0.24 \\
& $\mathrm{~b}$ & -0.02 & 0 & 1.22 \\
& $\mathrm{c}$ & 5.80 & 7.63 & 18.10 \\
& $\mathrm{~d}$ & 0.55 & 0.55 & 1.12 \\
\hline$f_{2}:$ & $\mathrm{a}$ & 0.86 & 0.8 & 0.68 \\
& $\mathrm{~b}$ & 0.19 & 0.20 & -0.06 \\
& $\mathrm{c}$ & 28.65 & 13.99 & 12.48 \\
& $\mathrm{~d}$ & 0.55 & 0.55 & 0.81 \\
\hline$f_{3}:$ & $\mathrm{a}$ & 0 & 0 & 0 \\
& $\mathrm{~b}$ & 1 & 1 & 1 \\
& $\mathrm{c}$ & 8.27 & 8.32 & 28.52 \\
& $\mathrm{~d}$ & 1.10 & 1.15 & 1.03 \\
\hline
\end{tabular}

Table A2. CFT-specific parameters of specific leaf area (SLA), minimum $\mathrm{C}: \mathrm{N}$ value of the leaves and the amount of the total $\mathrm{N}$ that is applied at the different developmental stages (DS), where DS $=0$ is sowing and DS $=0.5$ is half way into the vegetative phase. The remainder of the total fertiliser application (not listed in the table) is applied at $\mathrm{DS}=0.9$, which describes the vegetative phase just before flowering; see Olin et al. (2015) for more details.

\begin{tabular}{lllllc}
\hline Parameter & SW & WW & MA & Unit & Reference \\
\hline SLA & 35 & 35 & 45 & $\mathrm{~m}^{2} \mathrm{~kg}^{-1} \mathrm{C}^{-1}$ & \\
$\mathrm{C}: \mathrm{N}_{\min }$ & 15 & 15 & 15 & $\mathrm{~kg} \mathrm{C} \mathrm{kg}^{-1} \mathrm{~N}^{-1}$ & \\
$\mathrm{~N}_{\text {app,DS }=0}$ & $11 \%$ & $08 \%$ & $11 \%$ & fraction & Olin et al. (2015) \\
$\mathrm{N}_{\text {app,DS }=0.5}$ & $50 \%$ & $19 \%$ & $50 \%$ & fraction & Olin et al. (2015) \\
\hline
\end{tabular}



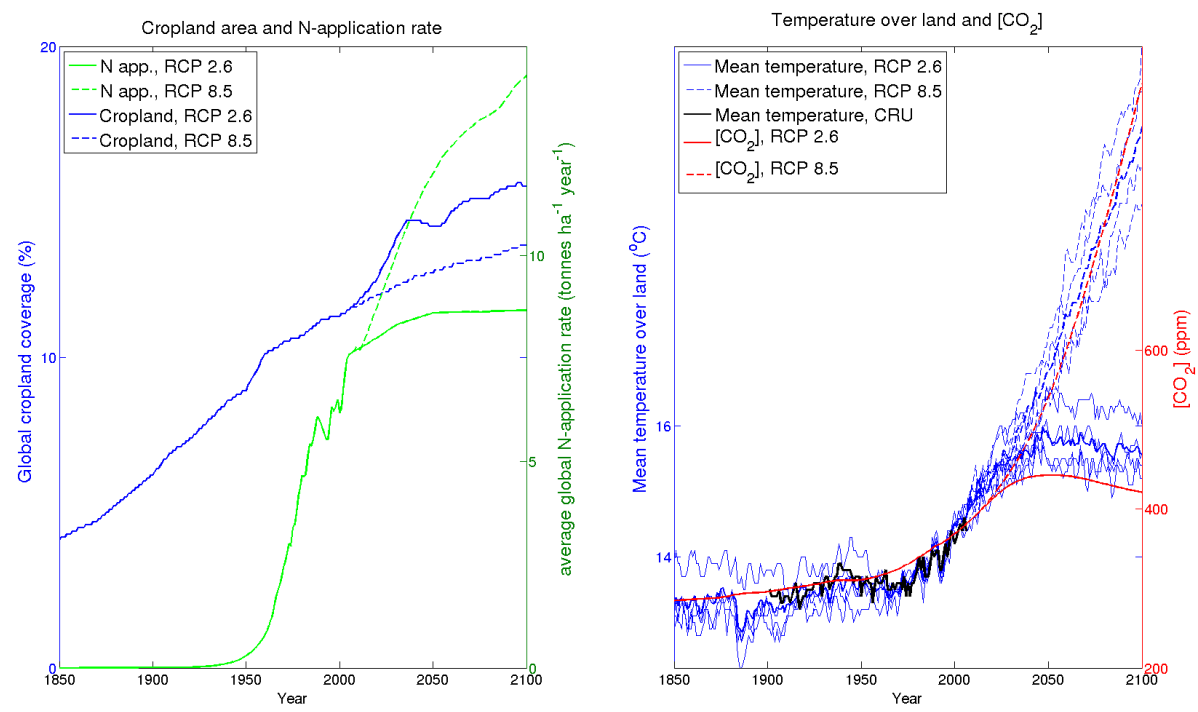

Figure A1. Input used for the simulations over the historic and scenario RCP2.6 and 85 periods: (a) global cropland cover (\%) from Hurtt et al. (2011) with mean N-fertiliser application rate (Stocker et al., 2013; Zaehle et al., 2010a); (b) $\left[\mathrm{CO}_{2}\right]$ and mean terrestrial temperature from the four GCMs (Sect. 2.2).

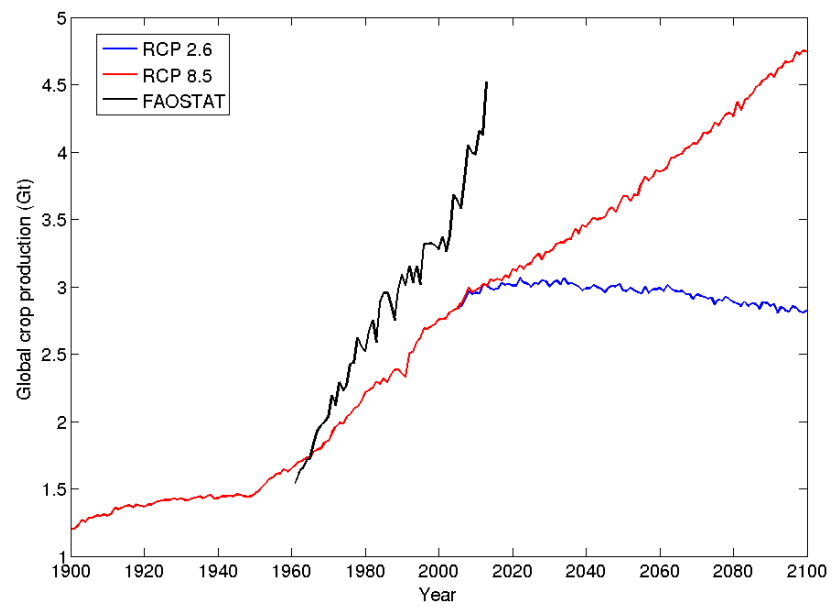

Figure A2. Global simulated mean crop production using the GCM climate (blue - RCP2.6; red - RCP8.5) compared to statistics from FAOSTAT (black). 


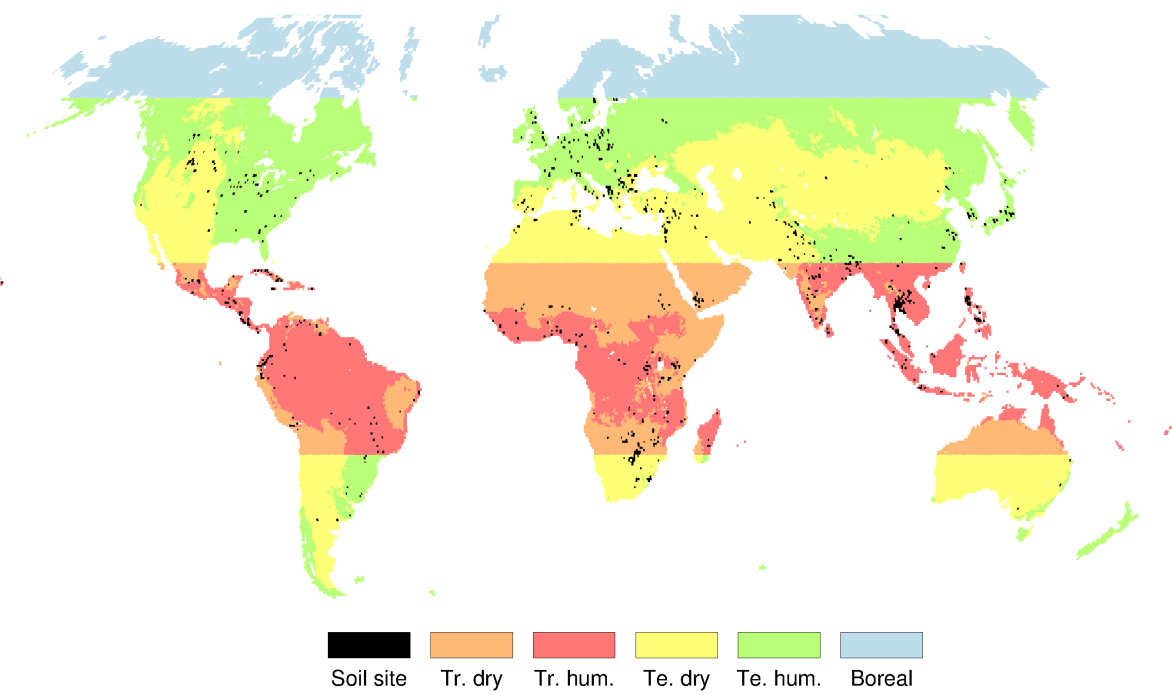

Figure A3. Climatic regions, as defined in Sect. 2.2.1 (tropical dry, tropical humid, temperate dry, temperate humid, boreal). Black pixels show the cropland soil column sites from Batjes (2005), used in the soil carbon comparison in this paper. 
Acknowledgements. This study contributes to the Strong Research Environment Land-Use Today and Tomorrow funded by the Swedish Research Council FORMAS (Contract No. 2112009-1682), to the Strategic Research Areas BECC and MERGE, and to projects within the Lund University Centre for Studies of Carbon Cycle and Climate Interactions (LUCCI). A. Arneth and T. A. M. Pugh acknowledge support from the European Commission in the FP 7 projects OPERAS (grant no. 308393) and LUC4C (grant no. 603542). M. Lindeskog was funded by the Mistra Swedish Research Programme for Climate, Impacts and Adaptation.

Edited by: S. Dekker

\section{References}

Ahlström, A., Schurgers, G., Arneth, A., and Smith, B.: Robustness and uncertainty in terrestrial ecosystem carbon response to CMIP5 climate change projections, Environ. Res. Lett., 7, 044008, doi:10.1088/1748-9326/7/4/044008, 2012.

Ahlström, A., Smith, B., Lindström, J., Rummukainen, M., and Uvo, C. B.: GCM characteristics explain the majority of uncertainty in projected 21 st century terrestrial ecosystem carbon balance, Biogeosciences, 10, 1517-1528, doi:10.5194/bg-10-15172013, 2013.

Arora, V. K.: Simulating energy and carbon fluxes over winter wheat using coupled land surface and terrestrial ecosystem models, Agr. Forest Meteorol., 118, 21-47, doi:10.1016/S01681923(03)00073-X, 2003.

Baker, J. M., Ochsner, T. E., Venterea, R. T., and Griffis, T. J.: Tillage and soil carbon sequestration - what do we really know?, Agr. Ecosyst. Environ., 118, 1-5, doi:10.1016/j.agee.2006.05.014, 2007.

Bationo, A., Christianson, C., and Klaij, M.: The effect of crop residue and fertilizer use on pearl millet yields in Niger, Fert. Res., 34, 251-258, doi:10.1007/BF00750571, 1993.

Batjes, N. H. .: ISRICE-WISE global data set of derived soil properties on a 0.5 by 0.5 degree grid (version 3.0), Report 08, ISRIC - World Soil Information, Wageningen, 2005.

Batjes, N. H.: Total carbon and nitrogen in the soils of the world, Eur. J. Soil Sci., 65, 10-21, doi:10.1111/ejss.12114_2, 2014.

Bondeau, A., Smith, P. C., Zaehle, S., Schaphoff, S., Lucht, W., Cramer, W., and Gerten, D.: Modelling the role of agriculture for the 20th century global terrestrial carbon balance, Global Change Biol., 13, 679-706, doi:10.1111/j.13652486.2006.01305.x, 2007.

Bouwman, L., Goldewijk, K. K., Van Der Hoek, K. W., Beusen, A. H. W., Van Vuuren, D. P., Willems, J., Rufino, M. C., and Stehfest, E.: Exploring global changes in nitrogen and phosphorus cycles in agriculture induced by livestock production over the 1900-2050 period, P. Natl. Acad. Sci. USA, 110, 2088220887, doi:10.1073/pnas.1012878108, 2013.

Boyer, E. W., Howarth, R. W., Galloway, J. N., Dentener, F. J., Green, P. A., and Vörösmarty, C. J.: Riverine nitrogen export from the continents to the coasts, Global Biogeochem. Cy., 20, GB1S91, doi:10.1029/2005GB002537, 2006.

Cameron, K., Di, H., and Moir, J.: Nitrogen losses from the soil/plant system: a review, Ann. Appl. Biol., 162, 145-173, doi:10.1111/aab.12014, 2013.
Chatskikh, D., Hansen, S., Olesen, J. E., and Petersen, B. M.: A simplified modelling approach for quantifying tillage effects on soil carbon stocks, Eur. J. Soil Sci., 60, 924-934, doi:10.1111/J.13652389.2009.01185.x, 2009.

Ciais, P., Sabine, C., Bala, G., Bopp, L., Brovkin, V., Canadell, J., Chhabra, A., DeFries, R., Galloway, J., Heimann, M., Jones, C., LeQuere, C., Myneni, R. B., Piao, S., and Thornton, P.: Carbon and other biogeochemical cycles, in: Climate Change 2013: The Physical Science Basis. Contribution of Working Group I to the Fifth Assessment Report of the Intergovernmental Panel on Climate Change, edited by: Stocker, T. F., Qin, D., Plattner, G.K., Tignor, M., Allen, S. K., Boschung, J., Nauels, A., Xia, Y., Bex, V., and Midgley, P. M., Cambridge University Press, Cambridge, UK and New York, NY, USA, 465-570, 2013.

Collatz, G., Ball, J., Grivet, C., and Berry, J. A.: Physiological and environmental regulation of stomatal conductance, photosynthesis and transpiration: a model that includes a laminar boundary layer, Agr. Forest Meteorol., 54, 107-136, doi:10.1016/01681923(91)90002-8, 1991.

Collatz, G., Ribas-Carbo, M., and Berry, J.: Coupled photosynthesis-stomatal conductance model for leaves of C4 plants, Funct. Plant Biol., 19, 519-538, 1992.

Collins, W. J., Bellouin, N., Doutriaux-Boucher, M., Gedney, N., Halloran, P., Hinton, T., Hughes, J., Jones, C. D., Joshi, M., Liddicoat, S., Martin, G., O'Connor, F., Rae, J., Senior, C., Sitch, S., Totterdell, I., Wiltshire, A., and Woodward, S.: Development and evaluation of an Earth-System model - HadGEM2, Geosci. Model Dev., 4, 1051-1075, doi:10.5194/gmd-4-10512011, 2011.

Deryng, D., Sacks, W. J., Barford, C. C., and Ramankutty, N.: Simulating the effects of climate and agricultural management practices on global crop yield, Global Biogeochem. Cy., 25, GB2006, doi:10.1029/2009GB003765, 2011.

Drewniak, B., Song, J., Prell, J., Kotamarthi, V. R., and Jacob, R.: Modeling agriculture in the Community Land Model, Geosci. Model Dev., 6, 495-515, doi:10.5194/gmd-6-495-2013, 2013.

Dufresne, J.-L., Foujols, M.-A., Denvil, S., Caubel, A., Marti, O., Aumont, O., Balkanski, Y., Bekki, S., Bellenger, H., Benshila, R., Bony, S., Bopp, L., Braconnot, P., Brockmann, P., Cadule, P., Cheruy, F., Codron, F., Cozic, A., Cugnet, D., de Noblet, N., Duvel, J.-P., Ethé, C., Fairhead, L., Fichefet, T., Flavoni, S., Friedlingstein, P., Grandpeix, J.-Y., Guez, L., Guilyardi, E., Hauglustaine, D., Hourdin, F., Idelkadi, A., Ghattas, J., Joussaume, S., Kageyama, M., Krinner, G., Labetoulle, S., Lahellec, A., Lefebvre, M.-P., Lefevre, F., Levy, C., Li, Z., Lloyd, J., Lott, F., Madec, G., Mancip, M., Marchand, M., Masson, S., Meurdesoif, Y., Mignot, J., Musat, I., Parouty, S., Polcher, J., Rio, C., Schulz, M., Swingedouw, D., Szopa, S., Talandier, C., Terray, P., Viovy, N., and Vuichard, N.: Climate change projections using the IPSL-CM5 Earth System Model: from CMIP3 to CMIP5, Clim. Dynam., 40, 2123-2165, doi:10.1007/s00382012-1636-1, 2013.

Elliott, J., Müller, C., Deryng, D., Chryssanthacopoulos, J., Boote, K. J., Büchner, M., Foster, I., Glotter, M., Heinke, J., Iizumi, T., Izaurralde, R. C., Mueller, N. D., Ray, D. K., Rosenzweig, C., Ruane, A. C., and Sheffield, J.: The Global Gridded Crop Model Intercomparison: data and modeling protocols for Phase 1 (v1.0), Geosci. Model Dev., 8, 261-277, doi:10.5194/gmd-8-261-2015, 2015. 
Evans, L.: Steps towards feeding the ten billion: a crop physiologists view, Plant Prod. Sci., 2, 3-9, 1999.

FAO: The state of food and agriculture, available at: http://www.fao.org/docrep/011/i0100e/i0100e00.htm (last access: 9 June 2015), 2008.

Follett, R.: Soil management concepts and carbon sequestration in cropland soils, Soil Till. Res., 61, 77-92, doi:10.1016/S01671987(01)00180-5, 2001.

Francis, C. A.: Biological efficiencies in multiple-cropping systems, Adv. Agron., 42, 1-42, doi:10.1016/S0065-2113(08)60522-2, 1989.

Galloway, J. N., Dentener, F. J., Capone, D. G., Boyer, E. W., Howarth, R. W., Seitzinger, S. P., Asner, G. P., Cleveland, C. C., Green, P. A., Holland, E. A., Karl, D. M., Michaels, A. F., Porter, J. H., Townsend, A. R., and Vörösmarty, C. J.: Nitrogen cycles: past, present, and future, Biogeochemistry, 70, 153-226, doi:10.1007/s10533-004-0370-0, 2004.

Gent, P. R., Danabasoglu, G., Donner, L. J., Holland, M. M., Hunke, E. C., Jayne, S. R., Lawrence, D. M., Neale, R. B., Rasch, P. J., Vertenstein, M., Worley, P. H., Yang, Z.-L., and Zhang, M.: The Community Climate System Model Version 4, J. Climate, 24, 4973-4991, doi:10.1175/2011JCLI4083.1, 2011.

Gerland, P., Raftery, A. E., Ševč́́ková, H., Li, N., Gu, D., Spoorenberg, T., Alkema, L., Fosdick, B. K., Chunn, J., Lalic, N., Bay, G., Buettner, T., Heilig, G. K., and Wilmoth, J.: World population stabilization unlikely this century, Science, 346, 234-237, doi:10.1126/science.1257469, 2014.

Grizetti, B.: Nitrogen as a Threat to European Water Quality, Cambridge University Press, Cambridge, UK and New York, NY, USA, doi:10.1017/CBO9780511976988.020, 2011.

Gruber, N. and Galloway, J. N.: An Earth-system perspective of the global nitrogen cycle, Nature, 451, 293-296, doi:10.1038/nature06592, 2008.

Guo, L. B. and Gifford, R. M.: Soil carbon stocks and land use change: a meta analysis, Global Change Biol., 8, 345-360, doi:10.1046/j.1354-1013.2002.00486.x, 2002.

Haberl, H., Erb, K. H., Krausmann, F., Gaube, V., Bondeau, A., Plutzar, C., Gingrich, S., Lucht, W., and Fischer-Kowalski, M.: Quantifying and mapping the human appropriation of net primary production in earth's terrestrial ecosystems, P. Natl. Acad. Sci. USA, 104, 12942-12947, doi:10.1073/pnas.0704243104, 2007.

Haxeltine, A. and Prentice, I. C.: A general model for the lightuse efficiency of primary production, Funct. Ecol., 10, 551-561, doi:10.2307/2390165, 1996.

Hertel, T.: The challenges of sustainably feeding a growing planet, Food Security, 7, 185-198, doi:10.1007/s12571-015-0440-2, 2015.

Hickler, T., Smith, B., Sykes, M. T., Davis, M. B., Sugita, S., and Walker, K.: Using a generalized vegetation model to simulate vegetation dynamics in northeastern USA, Ecology, 85, 519530, doi:10.1890/02-0344, 2004.

Houghton, R. A., House, J. I., Pongratz, J., van der Werf, G. R., DeFries, R. S., Hansen, M. C., Le Quéré, C., and Ramankutty, N.: Carbon emissions from land use and land-cover change, Biogeosciences, 9, 5125-5142, doi:10.5194/bg-9-5125-2012, 2012.

Hurtt, G., Chini, L., Frolking, S., Betts, R., Feddema, J., Fischer, G., Fisk, J., Hibbard, K., Houghton, R., Janetos, A., Jones, C., Kindermann, G., Kinoshita, T., Klein Goldewijk, K.,
Riahi, K., Shevliakova, E., Smith, S., Stehfest, E., Thomson, A., Thornton, P., van Vuuren, D., and Wang, Y.: Harmonization of land-use scenarios for the period 1500-2100: 600 years of global gridded annual land-use transitions, wood harvest, and resulting secondary lands, Climatic Change, 109, 117-161, doi:10.1007/s10584-011-0153-2, 2011.

IPCC: Revised 1996 IPCC Guidelines for National Greenhouse Gas Inventories, Organization for Economic Cooperation and Development (OECD), Washington, D.C., 1996.

Lal, R.: Soil carbon sequestration to mitigate climate change, Geoderma, 123, 1-22, doi:10.1016/j.geoderma.2004.01.032, 2004a.

Lal, R.: Carbon emission from farm operations, Environ. Int., 30, 981-990, doi:10.1016/j.envint.2004.03.005, 2004 b.

Lal, R.: Carbon sequestration, Philos. T. Roy. Soc. Lond. B, 363, 815-830, doi:10.1098/rstb.2007.2185, 2008.

Lal, R. and Bruce, J.: The potential of world cropland soils to sequester $\mathrm{C}$ and mitigate the greenhouse effect, Environ. Sci. Policy, 2, 177-185, doi:10.1016/S1462-9011(99)00012-X, 1999.

Lamarque, J.-F., Bond, T. C., Eyring, V., Granier, C., Heil, A., Klimont, Z., Lee, D., Liousse, C., Mieville, A., Owen, B., Schultz, M. G., Shindell, D., Smith, S. J., Stehfest, E., Van Aardenne, J., Cooper, O. R., Kainuma, M., Mahowald, N., McConnell, J. R., Naik, V., Riahi, K., and van Vuuren, D. P.: Historical (1850-2000) gridded anthropogenic and biomass burning emissions of reactive gases and aerosols: methodology and application, Atmos. Chem. Phys., 10, 7017-7039, doi:10.5194/acp10-7017-2010, 2010.

Le Quéré, C., Peters, G. P., Andres, R. J., Andrew, R. M., Boden, T. A., Ciais, P., Friedlingstein, P., Houghton, R. A., Marland, G., Moriarty, R., Sitch, S., Tans, P., Arneth, A., Arvanitis, A., Bakker, D. C. E., Bopp, L., Canadell, J. G., Chini, L. P., Doney, S. C., Harper, A., Harris, I., House, J. I., Jain, A. K., Jones, S. D., Kato, E., Keeling, R. F., Klein Goldewijk, K., Körtzinger, A., Koven, C., Lefèvre, N., Maignan, F., Omar, A., Ono, T., Park, G.-H., Pfeil, B., Poulter, B., Raupach, M. R., Regnier, P., Rödenbeck, C., Saito, S., Schwinger, J., Segschneider, J., Stocker, B. D., Takahashi, T., Tilbrook, B., van Heuven, S., Viovy, N., Wanninkhof, R., Wiltshire, A., and Zaehle, S.: Global carbon budget 2013, Earth Syst. Sci. Data, 6, 235-263, doi:10.5194/essd-6-235-2014, 2014.

Le Quéré, C., Moriarty, R., Andrew, R. M., Peters, G. P., Ciais, P., Friedlingstein, P., Jones, S. D., Sitch, S., Tans, P., Arneth, A., Boden, T. A., Bopp, L., Bozec, Y., Canadell, J. G., Chini, L. P., Chevallier, F., Cosca, C. E., Harris, I., Hoppema, M., Houghton, R. A., House, J. I., Jain, A. K., Johannessen, T., Kato, E., Keeling, R. F., Kitidis, V., Klein Goldewijk, K., Koven, C., Landa, C. S., Landschützer, P., Lenton, A., Lima, I. D., Marland, G., Mathis, J. T., Metzl, N., Nojiri, Y., Olsen, A., Ono, T., Peng, S., Peters, W., Pfeil, B., Poulter, B., Raupach, M. R., Regnier, P., Rödenbeck, C., Saito, S., Salisbury, J. E., Schuster, U., Schwinger, J., Séférian, R., Segschneider, J., Steinhoff, T., Stocker, B. D., Sutton, A. J., Takahashi, T., Tilbrook, B., van der Werf, G. R., Viovy, N., Wang, Y.-P., Wanninkhof, R., Wiltshire, A., and Zeng, N.: Global carbon budget 2014, Earth Syst. Sci. Data, 7, 47-85, doi:10.5194/essd-7-472015, 2015.

Levis, S., Hartman, M. D., and Bonan, G. B.: The Community Land Model underestimates land-use $\mathrm{CO}_{2}$ emissions by neglecting soil 
disturbance from cultivation, Geosci. Model Dev., 7, 613-620, doi:10.5194/gmd-7-613-2014, 2014.

Licker, R., Johnston, M., Foley, J. A., Barford, C., Kucharik, C. J., Monfreda, C., and Ramankutty, N.: Mind the gap: how do climate and agricultural management explain the "yield gap" of croplands around the world?, Global Ecol. Biogeogr., 19, 769782, doi:10.1111/j.1466-8238.2010.00563.x, 2010.

Lindeskog, M., Arneth, A., Bondeau, A., Waha, K., Seaquist, J., Olin, S., and Smith, B.: Implications of accounting for land use in simulations of ecosystem carbon cycling in Africa, Earth Syst. Dynam., 4, 385-407, doi:10.5194/esd-4-385-2013, 2013.

Liu, J., You, L., Amini, M., Obersteiner, M., Herrero, M., Zehnder, A. J. B., and Yang, H.: A high-resolution assessment on global nitrogen flows in cropland, P. Natl. Acad. Sci. USA, 107, 8035-8040, doi:10.1073/pnas.0913658107, 2010.

McGuire, A. D., Sitch, S., Clein, J. S., Dargaville, R., Esser, G., Foley, J., Heimann, M., Joos, F., Kaplan, J., Kicklighter, D. W., Meier, R. A., Melillo, J. M., Moore, B., Prentice, I. C., Ramankutty, N., Reichenau, T., Schloss, A., Tian, H., Williams, L. J., and Wittenberg, U.: Carbon balance of the terrestrial biosphere in the Twentieth Century: Analyses of $\mathrm{CO}_{2}$, climate and land use effects with four processbased ecosystem models, Global Biogeochem. Cy., 15, 183-206, doi:10.1029/2000GB001298, 2001.

Miller, P. A. and Smith, B.: Modelling tundra vegetation response to recent arctic warming, Ambio, 41, 281-291, doi:10.1007/s13280-012-0306-1, 2012.

Mitchell, T. D. and Jones, P. D.: An improved method of constructing a database of monthly climate observations and associated high-resolution grids, Int. J. Climatol., 25, 693-712, doi:10.1002/joc.1181, 2005.

Moss, R. H., Edmonds, J. A., Hibbard, K. A., Manning, M. R., Rose, S. K., van Vuuren, D. P., Carter, T. R., Emori, S., Kainuma, M., Kram, T., Meehl, G. A., Mitchell, J. F. B., Nakicenovic, N., Riahi, K., Smith, S. J., Stouffer, R. J., Thomson, A. M., Weyant, J. P., and Wilbanks, T. J.: The next generation of scenarios for climate change research and assessment, Nature, 463, 747-756, doi:10.1038/nature08823, 2010.

Mueller, N. D., West, P. C., Gerber, J. S., MacDonald, G. K., Polasky, S., and Foley, J. A.: A tradeoff frontier for global nitrogen use and cereal production, Environ. Res. Lett., 9, 054002, doi:10.1088/1748-9326/9/5/054002, 2014.

Nieder, R. and Benbi, D. K.: Carbon and Nitrogen in the Terrestrial Environment, Springer Science and Business Media, the Netherlands, 2008.

Ogle, S. M., Swan, A., and Paustian, K.: No-till management impacts on crop productivity, carbon input and soil carbon sequestration, Agr. Ecosyst. Environ., 149, 37-49, doi:10.1016/j.agee.2011.12.010, 2012.

Olin, S., Schurgers, G., Lindeskog, M., Wårlind, D., Smith, B., Bodin, P., Holmér, J., and Arneth, A.: Modelling the response of yields and tissue $\mathrm{C}: \mathrm{N}$ to changes in atmospheric $\mathrm{CO}_{2}$ and $\mathrm{N}$ management in the main wheat regions of western Europe, Biogeosciences, 12, 2489-2515, doi:10.5194/bg-12-2489-2015, 2015.

Park, S., Croteau, P., Boering, K. A., Etheridge, D. M., Ferretti, D., Fraser, P. J., Kim, K.-R., Krummel, P. B., Langenfelds, R. L., van Ommen, T. D., Steele, L. P., and Trudinger, C. M.: Trends and seasonal cycles in the isotopic composition of nitrous oxide since 1940, Nat. Geosci., 5, 261-265, doi:10.1038/ngeo1421, 2012.

Parton, W. J., Scurlock, J. M. O., Ojima, D. S., Gilmanov, T. G., Scholes, R. J., Schimel, D. S., Kirchner, T., Menaut, J.-C., Seastedt, T., Garcia Moya, E., Kamnalrut, A., and Kinyamario, J. I.: Observations and modeling of biomass and soil organic matter dynamics for the grassland biome worldwide, Global Biogeochem. Cy., 7, 785-809, doi:10.1029/93GB02042, 1993.

Penning de Vries, F. W. T., Jansen, D. M., Berge, H. F. M., and Bakema, A.: Simulation of Ecophysiological Processes of Growth in Several Annual Crops, Centre for Agricultural Publishing and Documentation, Wageningen, the Netherlands, 1989.

Phalan, B., Onial, M., Balmford, A., and Green, R. E.: Reconciling food production and biodiversity conservation: land sharing and land sparing compared, Science, 333, 1289-1291, doi:10.1126/science.1208742, 2011.

Piao, S., Sitch, S., Ciais, P., Friedlingstein, P., Peylin, P., Wang, X., Ahlström, A., Anav, A., Canadell, J. G., Cong, N., Huntingford, C., Jung, M., Levis, S., Levy, P. E., Li, J., Lin, X., Lomas, M. R., Lu, M., Luo, Y., Ma, Y., Myneni, R. B., Poulter, B., Sun, Z., Wang, T., Viovy, N., Zaehle, S., and Zeng, N.: Evaluation of terrestrial carbon cycle models for their response to climate variability and to $\mathrm{CO}_{2}$ trends, Global Change Biol., 19, 2117-2132, doi:10.1111/gcb.12187, 2013.

Pongratz, J., Reick, C. H., Houghton, R. A., and House, J. I.: Terminology as a key uncertainty in net land use and land cover change carbon flux estimates, Earth Syst. Dynam., 5, 177-195, doi:10.5194/esd-5-177-2014, 2014.

Portmann, F. T., Siebert, S., and Döll, P.: MIRCA2000 - Global monthly irrigated and rainfed crop areas around the year 2000: a new high-resolution data set for agricultural and hydrological modeling, Global Biogeochem. Cy., 24, GB1011, doi:10.1029/2008GB003435, 2010.

Powlson, D. S., Stirling, C. M., Jat, M. L., Gerard, B. G., Palm, C. A., Sanchez, P. A., and Cassman, K. G.: Limited potential of no-till agriculture for climate change mitigation, Nat. Clim. Change, 4, 678-683, doi:10.1038/nclimate2292, 2014.

Ramankutty, N., Evan, A. T., Monfreda, C., and Foley, J. A.: Farming the planet: 1. Geographic distribution of global agricultural lands in the year 2000, Global Biogeochem. Cy., 22, GB1003, doi:10.1029/2007GB002952, 2008.

Riahi, K., Rao, S., Krey, V., Cho, C., Chirkov, V., Fischer, G., Kindermann, G., Nakicenovic, N., and Rafaj, P.: RCP 8.5 - a scenario of comparatively high greenhouse gas emissions, Climatic Change, 109, 33-57, doi:10.1007/s10584-011-0149-y, 2011.

Richards, F. J.: A flexible growth function for empirical use, J. Exp. Bot., 10, 290-301, doi:10.1093/jxb/10.2.290, 1959.

Rockstrom, J., Steffen, W., Noone, K., Persson, A., Chapin, F. S., Lambin, E. F., Lenton, T. M., Scheffer, M., Folke, C., Schellnhuber, H. J., Nykvist, B., de Wit, C. A., Hughes, T., van der Leeuw, S., Rodhe, H., Sorlin, S., Snyder, P. K., Costanza, R., Svedin, U., Falkenmark, M., Karlberg, L., Corell, R. W., Fabry, V. J., Hansen, J., Walker, B., Liverman, D., Richardson, K., Crutzen, P., and Foley, J. A.: A safe operating space for humanity, Nature, 461, 472-475, doi:10.1038/461472a, 2009.

Rosenzweig, C., Elliott, J., Deryng, D., Ruane, A. C., Müller, C., Arneth, A., Boote, K. J., Folberth, C., Glotter, M., Khabarov, N., Neumann, K., Piontek, F., Pugh, T. A. M., Schmid, E., Stehfest, E., Yang, H., and Jones, J. W.: Assessing agricultural risks 
of climate change in the 21 st century in a global gridded crop model intercomparison, P. Natl. Acad. Sci. USA, 111, 32683273, doi:10.1073/pnas.1222463110, 2014.

Schlesinger, W. H.: Carbon sequestration in soils: some cautions amidst optimism, Agr. Ecosyst. Environ., 82, 121-127, doi:10.1016/S0167-8809(00)00221-8, 2000.

Sitch, S., Smith, B., Prentice, I. C., Arneth, A., Bondeau, A., Cramer, W., Kaplan, J. O., Levis, S., Lucht, W., Sykes, M. T., Thonicke, K., and Venevsky, S.: Evaluation of ecosystem dynamics, plant geography and terrestrial carbon cycling in the LPJ dynamic global vegetation model, Global Change Biol., 9, 161185, doi:10.1046/j.1365-2486.2003.00569.x, 2003.

Sitch, S., Huntingford, C., Gedney, N., Levy, P., Lomas, M., Piao, S., Betts, R., Ciais, P., Cox, P., Friedlingstein, P., Jones, C., Prentice, I., and Woodward, F.: Evaluation of the terrestrial carbon cycle, future plant geography and climate-carbon cycle feedbacks using five Dynamic Global Vegetation Models (DGVMs), Global Change Biol., 14, 2015-2039, 2008.

Smil, V.: Nitrogen in crop production: an account of global flows, Global Biogeochem. Cy., 13, 647-662, doi:10.1029/1999GB900015, 1999.

Smith, B., Prentice, I. C., and Sykes, M. T.: Representation of vegetation dynamics in the modelling of terrestrial ecosystems: comparing two contrasting approaches within European climate space, Global Ecol. Biogeogr., 10, 621-637, 2001.

Smith, B., Wårlind, D., Arneth, A., Hickler, T., Leadley, P., Siltberg, J., and Zaehle, S.: Implications of incorporating $\mathrm{N}$ cycling and $\mathrm{N}$ limitations on primary production in an individualbased dynamic vegetation model, Biogeosciences, 11, 20272054, doi:10.5194/bg-11-2027-2014, 2014.

Smith, P.: Soils as carbon sinks: the global context, Soil Use Manage., 20, 212-218, doi:10.1111/j.1475-2743.2004.tb00361.x, 2004a.

Smith, P.: Carbon sequestration in croplands: the potential in Europe and the global context, Eur. J. Agron., 20, 229-236, doi:10.1016/j.eja.2003.08.002, 2004b.

Smith, W., Grant, B., Campbell, C., McConkey, B., Desjardins, R., Kröbel, R., and Malhi, S.: Crop residue removal effects on soil carbon: measured and inter-model comparisons, Agr. Ecosyst. Environ., 161, 27-38, doi:10.1016/j.agee.2012.07.024, 2012.

Spano, G., Di Fonzo, N., Perrotta, C., Platani, C., Ronga, G., Lawlor, D. W., Napier, J. A., and Shewry, P. R.: Physiological characterization of "stay green" mutants in durum wheat, J. Exp. Bot., 54, 1415-1420, doi:10.1093/jxb/erg150, 2003.

Steffen, W., Broadgate, W., Deutsch, L., Gaffney, O., and Ludwig, C.: The trajectory of the anthropocene: the great acceleration, Anthrop. Rev., 2, 81-98, doi:10.1177/2053019614564785, 2015.

Stehfest, E., Heistermann, M., Priess, J. A., Ojima, D. S., and Alcamo, J.: Simulation of global crop production with the ecosystem model DayCent, Ecol. Model., 209, 203-219, doi:10.1016/j.ecolmodel.2007.06.028, 2007.

Stevens, B., Giorgetta, M., Esch, M., Mauritsen, T., Crueger, T., Rast, S., Salzmann, M., Schmidt, H., Bader, J., Block, K., Brokopf, R., Fast, I., Kinne, S., Kornblueh, L., Lohmann, U., Pincus, R., Reichler, T., and Roeckner, E.: Atmospheric component of the MPI-M Earth System Model: ECHAM6, J. Adv. Model. Earth Syst., 5, 146-172, doi:10.1002/jame.20015, 2013.
Stocker, B. D., Roth, R., Joos, F., Spahni, R., Steinacher, M., Zaehle, S., Bouwman, L., Xu-Ri, and Prentice, I. C.: Multiple greenhouse-gas feedbacks from the land biosphere under future climate change scenarios, Nat. Clim. Change, 3, 666-672, doi:10.1038/nclimate1864, 2013.

Stockmann, U., Adams, M., Crawford, J., Field, D., Henakaarchchi, N., Jenkins, M., Minasny, B., McBratney, A., Courcelles, V., Singh, K., Wheeler, I., Abbott, L., Angers, D., Baldock, J., Bird, M., Brookes, P., Chenu, C., Jastrow, J., Lal, R., Lehmann, J., O’Donnell, A., Parton, W., Whitehead, D., and Zimmermann, M.: The knowns, known unknowns and unknowns of sequestration of soil organic carbon, Agr. Ecosyst. Environ., 164, 80-99, doi:10.1016/j.agee.2012.10.001, 2013.

Tarnocai, C., Canadell, J. G., Schuur, E. A. G., Kuhry, P., Mazhitova, G., and Zimov, S.: Soil organic carbon pools in the northern circumpolar permafrost region, Global Biogeochem. Cy., 23, GB2023, doi:10.1029/2008GB003327, 2009.

Taylor, K. E., Stouffer, R. J., and Meehl, G. A.: An overview of CMIP5 and the experiment design, B. Am. Meteorol. Soc., 93, 485-498, doi:10.1175/BAMS-D-11-00094.1, 2011.

Thornton, P. E., Doney, S. C., Lindsay, K., Moore, J. K., Mahowald, N., Randerson, J. T., Fung, I., Lamarque, J.-F., Feddema, J. J., and Lee, Y.-H.: Carbon-nitrogen interactions regulate climate-carbon cycle feedbacks: results from an atmosphereocean general circulation model, Biogeosciences, 6, 2099-2120, doi:10.5194/bg-6-2099-2009, 2009.

Tilman, D., Cassman, K. G., Matson, P. A., Naylor, R., and Polasky, S.: Agricultural sustainability and intensive production practices, Nature, 418, 671-677, doi:10.1038/nature01014, 2002.

Van Kessel, C., Horwath, W. R., Hartwig, U., Harris, D., and Lüscher, A.: Net soil carbon input under ambient and elevated $\mathrm{CO}_{2}$ concentrations: isotopic evidence after 4 years, Global Change Biol., 6, 43-444, doi:10.1046/j.13652486.2000.00318.x, 2000.

Vitousek, P. M., Mooney, H. A., Lubchenco, J., and Melillo, J. M.: Human domination of earth's ecosystems, Science, 277, 494499, doi:10.1126/science.277.5325.494, 1997.

Waha, K., van Bussel, L. G. J., Muller, C., and Bondeau, A.: Climate-driven simulation of global crop sowing dates, Global Ecol. Biogeogr., 21, 247-259, doi:10.1111/j.14668238.2011.00678.x, 2011.

Waha, K., Müller, C., Bondeau, A., Dietrich, J., Kurukulasuriya, P., Heinke, J., and Lotze-Campen, H.: Adaptation to climate change through the choice of cropping system and sowing date in sub-Saharan Africa, Global Environ. Change, 23, 130-143, doi:10.1016/j.gloenvcha.2012.11.001, 2013.

Wania, R., Ross, I., and Prentice, I. C.: Integrating peatlands and permafrost into a dynamic global vegetation model: 1 . Evaluation and sensitivity of physical land surface processes, Global Biogeochem. Cy., 23, GB3014, doi:10.1029/2008GB003412, 2009.

Wårlind, D., Smith, B., Hickler, T., and Arneth, A.: Nitrogen feedbacks increase future terrestrial ecosystem carbon uptake in an individual-based dynamic vegetation model, Biogeosciences, 11, 6131-6146, doi:10.5194/bg-11-6131-2014, 2014.

Wilhelm, W. W., Johnson, J. M. F., Hatfield, J. L., Voorhees, W. B., and Linden, D. R.: Crop and soil productivity response to corn residue removal, this paper is a joint contribution of the USDA- 
ARS and the Agricultural Research Division of the University of Nebraska, published as Journal Ser. no. 13949, Agron. J., 96, 1-17, 2004.

Wramneby, A., Smith, B., Zaehle, S., and Sykes, M. T.: Parameter uncertainties in the modelling of vegetation dynamics effects on tree community structure and ecosystem functioning in European forest biomes, Ecol. Model., 216, 277-290, doi:10.1016/j.ecolmodel.2008.04.013, 2008.

Yang, X., Wittig, V., Jain, A. K., and Post, W.: Integration of nitrogen cycle dynamics into the Integrated Science Assessment Model for the study of terrestrial ecosystem responses to global change, Global Biogeochem. Cy., 23, GB3474, doi:10.1029/2009GB003474, 2009.

Zaehle, S. and Dalmonech, D.: Carbon-nitrogen interactions on land at global scales: current understanding in modelling climate biosphere feedbacks, Curr. Opin. Environ. Sustain., 3, 311-320, doi:10.1016/j.cosust.2011.08.008, 2011.
Zaehle, S. and Friend, A. D.: Carbon and nitrogen cycle dynamics in the O-CN land surface model: 1. Model description, site-scale evaluation, and sensitivity to parameter estimates, Global Biogeochem. Cy., 24, GB1005, doi:10.1029/2009GB003521, 2010.

Zaehle, S., Friedlingstein, P., and Friend, A. D.: Terrestrial nitrogen feedbacks may accelerate future climate change, Geophys. Res. Lett., 37, L01401, doi:10.1029/2009GL041345, 2010a.

Zaehle, S., Friend, A. D., Friedlingstein, P., Dentener, F., Peylin, P., and Schulz, M.: Carbon and nitrogen cycle dynamics in the O$\mathrm{CN}$ land surface model: 2 . Role of the nitrogen cycle in the historical terrestrial carbon balance, Global Biogeochem. Cy., 24, GB3522, doi:10.1029/2009GB003522, 2010b.

Zaehle, S., Ciais, P., Friend, A. D., and Prieur, V.: Carbon benefits of anthropogenic reactive nitrogen offset by nitrous oxide emissions, Nat. Geosci., 4, 601-605, doi:10.1038/ngeo1207, 2011. 